\title{
Effects of thermocline deepening on lake plankton communities
}

\author{
Ariane Cantin, Beatrix E. Beisner, John M. Gunn, Yves T. Prairie, and \\ Jennifer G. Winter
}

\begin{abstract}
Theory predicts, and some evidence demonstrates that in lakes, the depth of the thermocline can have a large structural influence on the spatial distribution, and strongly influences the composition of plankton communities. However, experimental assessments of responses of the planktonic food web to thermocline depth have not yet been done at the whole-basin scale. We conducted an experiment wherein we artificially lowered the thermocline in an isolated basin of a three-basin lake, maintaining another isolated basin as a control. The vertical distribution and taxonomic composition of both phytoplankton and zooplankton were monitored throughout the summer months. Greater phytoplankton production, especially in the epilimnion, attributable mainly to increases in the chlorophytes was observed with thermocline deepening, but at the deepest thermoclines, production was limited. Total zooplankton biomass was unaffected by thermocline depth, suggesting top-down control by predators. Zooplankton biomass peaks were less pronounced in the manipulated basin, but tended to follow the thermocline whether at its normal position or as it was deepened. Zooplankton composition was significantly altered by large increases in densities of predatory cyclopoid copepods and rotifers; taxa commonly found in turbulent environments. Overall, both phytoplankton and zooplankton communities demonstrated important shifts in structure and composition in response to thermocline deepening.
\end{abstract}

Résumé : La théorie prédit et certaines données démontrent que la profondeur de la thermocline dans les lacs peut avoir une grande influence structurale tant sur la répartition spatiale que sur la composition des communautés planctoniques. Cependant, les réactions du réseau alimentaire planctonique à la profondeur de la thermocline n'ont pas encore été étudiées à l'échelle d'un bassin entier. Nous avons mené une expérience dans laquelle nous avons abaissé artificiellement la thermocline dans un bassin isolé dans un lac qui comporte trois bassins, tout en maintenant un autre bassin isolé comme témoin. Nous avons suivi la répartition verticale et la composition taxonomique à la fois du phytoplancton et du zooplancton au cours des mois d'été. Nous avons observé une production accrue du phytoplancton, particulièrement dans l'épilimnion, attribuable principalement à l'accroissement des chlorophytes lors de baisse de la thermocline; aux profondeurs les plus grandes de la thermocline, la production est cependant réduite. La biomasse totale du zooplancton est inaffectée par la profondeur de la thermocline, ce qui laisse croire à un contrôle descendant par les prédateurs. Les pics de biomasse du zooplancton sont moins prononcés dans le bassin manipulé, mais ils ont tendance à suivre la thermocline, qu'elle soit à sa profondeur normale ou plus profonde. La composition du zooplancton est significativement modifiée par des forts accroissements de densité des copépodes cyclopoïdes et des rotifères prédateurs, des taxons couramment retrouvés dans les environnements turbulents. Globalement, les communautés phytoplanctoniques et zooplanctoniques montrent toutes deux des changements importants en réaction à la baisse de la thermocline.

[Traduit par la Rédaction]

\section{Introduction}

Studies of the ecology of lake plankton have provided a wealth of insight into the interactions between abiotic factors and biotic ones such as competition and predation. Theoretical investigations into the effect of lake thermal stratification on phytoplankton communities have been espe- cially fruitful (e.g., Huisman and Weissing 1995; Klausmeier and Litchman 2001; Diehl 2002) and have provided predictions for the occurrence of plankton blooms, among others. This theoretical work relates the characteristic thermal structure of dimictic lakes in summer, specifically thermocline depth, to gradients of light (decreasing with depth) and nutrients (increasing with depth, especially at or below

Received 3 February 2010. Accepted 26 September 2010. Published on the NRC Research Press Web site at cjfas.nrc.ca on 2 February 2011.

J21643

Paper handled by Associate Editor Gesa Antoine Weyhenmeyer.

A. Cantin, B.E. Beisner, ${ }^{1}$ and Y.T. Prairie. Department of Biological Sciences, Université du Québec at Montréal, Case Postale 8888, Succursale Centre-Ville, Montréal, QC H3C 3P8, Canada.

J.M. Gunn. Cooperative Freshwater Ecology Unit, Biology Department, Laurentian University, 935 Ramsey Lake Road, Sudbury, ON P3E 2C6, Canada.

J.G. Winter. Department of Ontario Ministry of the Environment, Environmental Monitoring and Reporting Branch, 125 Resources

Road, Toronto, ON M9P 3V6, Canada.

${ }^{1}$ Corresponding author (e-mail: beisner.beatrix@uqam.ca). 
the thermocline). The opposing gradients in these growth factors for phytoplankton create a situation where different phytoplankton groups can be favoured under altered thermal structures as their depth optima change with thermocline depth (the "algal game"; Klausmeier and Litchman 2001). Furthermore, multilake observational studies have supported theoretical predictions for the critical role of thermocline depth for phytoplankton communities (e.g., Longhi and Beisner 2009). Experiments that directly test such theories have only been done in mesocosms (e.g., Diehl et al. 2002; Berger et al. 2007; Jäger et al. 2008) or in lakes that have been completely mixed to test the role of the presence or absence of a thermocline (e.g., Heo and Kim 2004; Becker et al. 2006). To date, there have been no whole-lake studies that experimentally manipulate thermocline depth, thereby not only directly testing the theory, but also providing estimates of whole-community change in the presence of natural food webs at relevant spatial scales.

At a macroscopic scale, thermocline depth is largely determined by measures of lake size such as length or fetch (Straskraba 1980; Patalas 1984; Gorham and Boyce 1989), and is modulated by differences in heat flux (Schindler 1997) and factors affecting light penetration (Fee et al. 1996), such as concentration of coloured dissolved organic carbon (DOC), especially in smaller lakes (<500 ha) (Snucins and Gunn 2000). The effect of lake size on thermocline depth reflects the differential effect of wind-induced mixing in small vs. large lakes (e.g., George 1981), and so, any changes in wind regimes are likely to affect a lake's thermal structure. Increases in wind levels at lake surfaces can result from the removal of riparian forest through fire or clearcutting activities (Schindler et al. 1990; France 1997; Scully et al. 2000). Also, some scenarios of climate change predict deeper thermoclines in northern lakes through declines in coloured DOC concentrations, because temperature increases and longer periods of drought are expected to decrease the amount of catchment organic matter brought to lakes by precipitation runoff (Fee et al. 1996; Schindler et al. 1996). On the other hand, some have predicted shallower thermoclines with climate change as a result of expected increases in air temperature, which would warm lake epilimnia, resulting in more strongly stratified lakes with shallower thermoclines (DeStasio et al. 1996; Straile et al. 2003). Whether climate change will lead to deeper or shallower thermoclines remains equivocal, but in either case, a change in thermocline depth is expected.

Changes to the thermal structure of lakes can have various abiotic effects with consequences for biological production. Deeper vertical mixing of the water column could lead to a greater oxygenation of the hypolimnion, reducing anoxia at depth (Scully et al. 2000). Further, because nutrient concentrations are usually higher in the deeper, hypolimnetic waters of stratified lakes, increased vertical mixing should make these more available to epilimnetic plankton communities (Harris and Griffiths 1987; Kristensen et al. 1992; Weithoff et al. 2000). Furthermore, the increased exposure of a larger amount of lake sediment to warm epilimnetic water following thermocline deepening should lead to greater mineralization rate and associated nutrient release.

For the phytoplankton, lake stratification imposes a vertical structure that determines the distribution of, and expo- sure to, important abiotic conditions (e.g., density, temperature, viscosity, nutrients, and light availability) with the potential to influence primary production (e.g., Reynolds 1984). Sverdrup (1953) was the first to derive a model showing that phytoplankton blooms were only possible if the thermocline depth was shallower than some critical depth where there was enough light to ensure that primary production exceeded respiration. Subsequent theory has incorporated nutrient levels as a second critical driver of phytoplankton dynamics in stratified water columns. Klausmeier and Litchman (2001) proposed a model of vertical phytoplankton distribution for poorly mixed water columns, and found that the phytoplankton maximum occurs at the depth for which they are equally limited by light and nutrients. Models of mixed water columns (Huisman and Weissing 1995; Diehl 2002) have also found that the light:nutrient ratio is an important determinant of phytoplankton dynamics. These models incorporate not only competition between species but further acknowledge the importance of algal sinking velocity for vertical distribution patterns (e.g., Huisman et al. 1999; Jäger et al. 2010). With an increase in thermocline depth, fast sinking less-motile species should remain in the epilimnetic mixed layer longer (Diehl et al. 2002; Becker et al. 2006; Berger et al. 2006), but should be exposed to more fluctuations in light under turbulent conditions (Huisman et al. 1999). Under conditions where nonmotile species dominate, depth-integrated (areal) phytoplankton biomass can be expected to follow a unimodal distribution with thermocline depth, being limited by sedimentation loss when thermoclines are shallow, by light when thermoclines are deep, and by nutrient re-supply rates at intermediate depths (Diehl 2002). However, by explicitly considering the interaction of different degrees of turbulence with thermocline depth, Jäger et al. (2010) have recently refined these predictions, and further, expect a monotonic increase in phytoplankton biomass with thermocline depth under low to intermediate turbulence, because neither sinking, nor light, nor nutrients limit growth particularly strongly. Finally, a negative relationship with thermocline depth is expected if the phytoplankton community is dominated by motile species (Diehl 2002; Ptacnik et al. 2003).

An altered phytoplankton community composition is also expected with modified water column thermal structure. Deeper thermoclines may favour species that are less sensitive to large fluctuations in light levels, as is the case for certain chlorophyte and diatom species (Litchman 2000). Cryptophytes and chrysophytes, which are often very motile species and can have mixotrophic feeding strategies, could further benefit from a deeper thermocline because of their low light:nutrient needs (Ptacnik et al. 2003). Such phytoplankton can capitalize on higher nutrient levels and bacterial biomass present at the edge of the hypolimnion because of their tolerance for lower light than is the case for many other phytoplankton. On the other hand, buoyant cyanobacteria should be negatively affected by deeper thermoclines, because they will be unable to maintain their preferred shallow position with deeper mixed layers and will be subject to shading by other species (Huisman et al. 2004). Fast sinking algae like diatoms (heavy and nonmotile) could benefit from greater thermocline depth, as they will remain in the mixed 
layer longer (Reynolds 1984; Diehl 2002; Winder et al. 2009).

Relative to the phytoplankton, the vertical distribution of the more motile zooplankton can be linked not only to abiotic forces (temperature, turbulence) but also to the distribution of their prey (phytoplankton) and predators (other invertebrates and fishes), all of which can have relationships with thermocline depth (e.g., Leibold 1990; Pinel-Alloul 1995; Masson et al. 2004). A more heterogeneous distribution of zooplankton has been linked to stronger thermal stratification through both the active and passive movements of individuals (Thackeray et al. 2006). The effects of turbulence, potentially associated with deeper thermoclines in lakes, has been little studied with respect to zooplankton, but studies in rivers show that some species, particularly rotifers and other small zooplankton, are more tolerant to turbulence than larger cladoceran species (Pace et al. 1992; Basu and Pick 1996). Furthermore, increased mixing across a deeper epilimnion (larger vertical excursions) could increase zooplankton encounter rates with prey, mates, and predators, all of which can cause variation in population vitality rates and alter zooplankton community structure (Rothschild and Osborn 1988; Visser et al. 2001).

In this whole-lake study, we experimentally examined the effects of thermocline deepening on plankton biomass production, vertical distribution, and taxonomic composition. Responses in both the phytoplankton and zooplankton communities were studied, along with various abiotic variables. To our knowledge, our experiment is the first to be done at the "whole lake" (basin) scale without completely destratifying the water column. We predicted that with a deeper thermocline, the position of the metalimnetic phytoplankton biomass peak (chlorophyll $a$ ) would be found deeper in the water column, as it is largely determined by density changes between thermally stratified layers. With thermocline deepening we expected an initial increase in phytoplankton biomass across the mixed layer as sedimentation losses are reduced, followed by declining biomasses for the deepest thermoclines because of light limitation with depth. Furthermore, we expected compositional changes in the phytoplankton community with $(i)$ declines in cyanobacteria, (ii) increases in groups tolerant of shade or light fluctuations and, (iii) increases in less motile species. For zooplankton, we predicted that vertical distributions would follow phytoplankton variation with a deeper biomass peak and with mixed layer biomass declines if primary producer biomass was reduced in the epilimnion. We also expected some variation in zooplankton taxonomic composition, related to changes in prey composition and the differing abilities of different types of zooplankton to survive under conditions of larger vertical mixing depths.

\section{Materials and methods}

\section{Study site}

The experiment was carried out in an oligotrophic lake, Lac Croche $\left(45^{\circ} 59^{\prime} 35^{\prime \prime} \mathrm{N}, 74^{\circ} 00^{\prime} 28^{\prime \prime} \mathrm{W}\right)$, located at the Station de Biologie des Laurentides in St.-Hippolyte, Quebec, Canada. It is a small headwater lake of $0.19 \mathrm{~km}^{2}$, with a relatively undisturbed watershed of $0.7 \mathrm{~km}^{2}$. The relative absence of human disturbance around Lac Croche makes it an ideal lake for experimental manipulation because of reduced variation linked to anthropogenic disturbance. This lake was also chosen because it has three relatively distinct basins (Fig. 1). Control Basin 1 (B1) is separated from the intermediate buffer Basin 2 (B2) by a narrow and very shallow section (maximum depth of $2 \mathrm{~m}$ ). B2 is separated from the experimental Basin 3 (B3) by an island, a very shallow (1 $\mathrm{m})$ section on the south side and, on the north side, a water section approximately $120-\mathrm{m}$ wide and $6-\mathrm{m}$ deep. In November 2007, a black polyethylene curtain was placed across this deeper section to more completely isolate B3 from the rest of the lake. However, the shallow link on the south side of the island between B3 and B2 was left open. All three basins had maximum depths of 11-13 m. A sampling dock was anchored above the deepest point in each basin (Fig. 1).

\section{Experimental lake mixing}

The experimental design consisted of a "Before-After Control-Impact" (BACI) design. Preliminary sampling during the summer of 2007 provided the "Before" data. Sampling during summer 2008 when the experimental mixing was initiated provided the "After" data. B1 provided the "Control" data, and the B3 basin provided the "Impact" data, with the intermediate basin, B2, acting as a buffer (but note that originally, B2 was considered a second control). To simulate the deepening of the thermocline induced by increased wind, a solar powered lake mixer (Solar Bee ${ }^{\circledR}$, $\mathrm{H}_{2} \mathrm{O}$ Logics Inc., Sherwood Park, Alberta, Canada) was used in B3. The mixer uses an electric-motor-driven propeller to lift cold water from the bottom of the lake to the surface, where the water spread across the surface and warmed by the sun, increasing the volume of warm water in the epilimnion and thereby deepening this upper stratum. The mixer was installed on the surface of the ice during winter 2008 and started up as soon as the ice melted in mid-April 2008 , by drawing water from an $8-\mathrm{m}$ depth to the surface. The Solar Bee was stopped on 15 August 2008 (day 228 of year).

\section{Sampling}

\section{Schedule}

Biotic and abiotic variables were sampled from the sampling docks at the deepest point in each basin. In 2007 there were six sampling occasions occurring biweekly between 20 June (day 171 of year) and 29 August (day 241). In 2008, basins were sampled from May through to the end of October. From this sampling it was determined that the deeper thermocline in B3 only became established around day 178 (26 June) and the lake became relatively isothermal around day 261 (17 September). Thus, we initially planned to use data only from the biweekly dates between day 178 and 261 in 2008 in the analyses. However, because the BACI design used requires matching of dates in different years to remove seasonal effects, and because sampling in 2007 was not as extensive, data from only six sampling dates starting on day 178 and ending on day 247, 2008 could be used. For each sampling excursion, all data were collected within one day, in the same order, and in as short a time period as possible (from 1000 to $1600 \mathrm{~h}$ ). 
Fig. 1. Bathymetric map of Lac Croche (Courtesy of Station de Biologie des Laurentides, University of Montréal, Montréal, Quebec). The stars represent the sampling docks, the broken line represents the curtain, and the crossed circle indicates the location of the the SolarBee ${ }^{\circledR}$. Inset map shows the approximate location of the lake in the Laurentians region of Quebec, Canada.

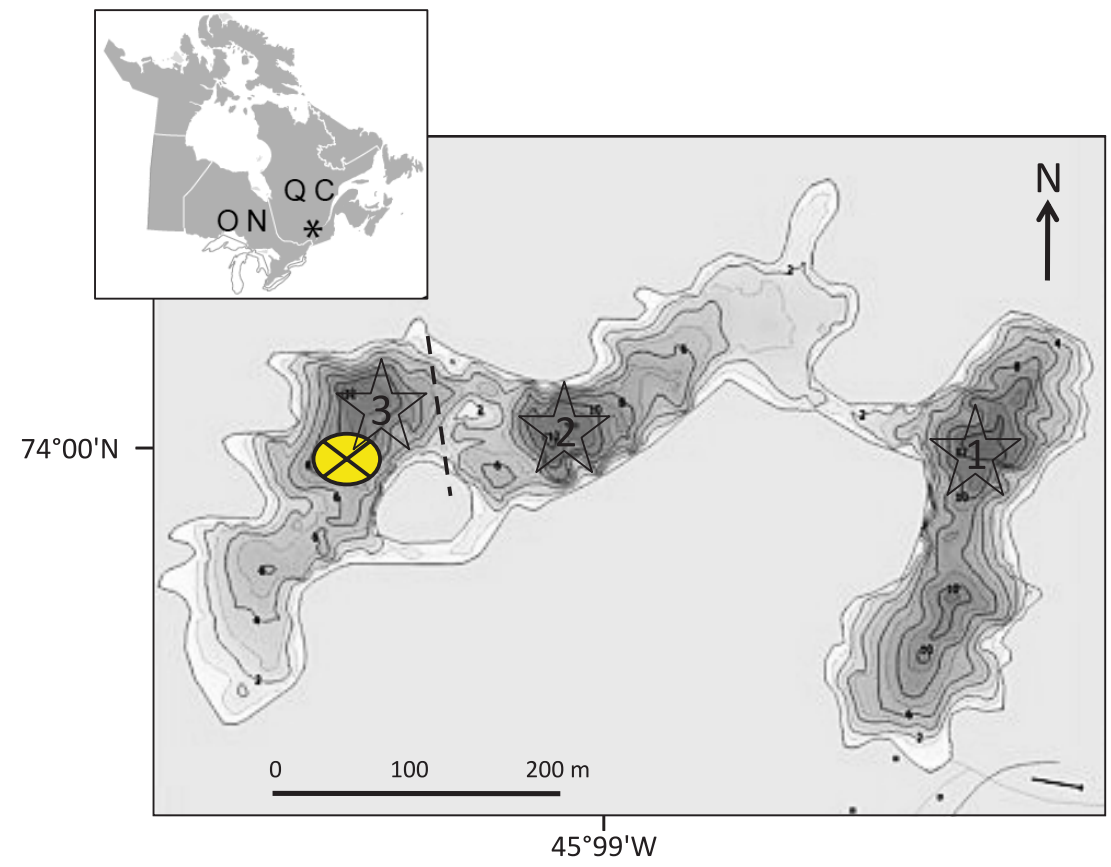

The two exceptions to this data collection schedule were for the phytoplankton taxonomic samples for which six biweekly samples in 2008 and only two biweekly samples in 2007 were processed in the laboratory for taxonomic assessment, as these served mainly to supplement the FluoroProbe results. The second exception was for the zooplankton biomass profiles (LOPC data; see Biotic profile data section) for which there was no 2007 data, owing to a breakdown of the equipment. These data were thus analyzed in a slightly modified manner as discussed in the section "Data processing and analyses".

\section{Abiotic variables}

Temperature and percent dissolved oxygen saturation (\%DO) profiles at every $1 \mathrm{~m}$ over the entire water column were collected using a YSI 6600 multi-sonde on each sampling occasion in 2007 and 2008. Biweekly water samples for nutrients were taken from the epilimnion ( $2 \mathrm{~m}$ depth) using a 2 L Van Dorn bottle, in 2007, from all basins, and in profile (at $0,2,4,6$, and $8 \mathrm{~m}$ depths) in 2008 but only in B2 and B3, as B2 was originally intended to be a second control. This was done as a cost-saving measure, and thus we have no results for nutrients in 2008 from the true control (B1). We later discovered thermocline deepening in B2 as well, albeit to a lesser extent than in B3, likely owing to heat transfer through the curtain. Thus, nutrient comparisons are of limited interpretation value. Water samples for nutrients were analysed in the laboratory for total phosphorus (TP), dissolved inorganic carbon (DIC), and dissolved organic carbon (DOC). TP was measured spectrophotometrically by the molybdenum-blue method after persulfate digestion (Griesbach and Peters 1991). DIC and DOC concentrations in filtered water samples (surfactant-free membrane filters) were measured after acidification (phosphoric acid) for DIC followed by sodium persulfate oxidation for
DOC on a 1010 TOC analyzer (O.I. Analytical, College Station, Texas, USA).

\section{Biotic profile data}

Phytoplankton biomass in profile for the major spectral groups was estimated using a submersible spectrofluorometer (FluoroProbe, bbe-Moldaenke, Kiel, Germany). The instrument measures fluorometrically the concentration of chlorophyll $a$ ( $\operatorname{chl} a$ ) of four major spectral groups of phytoplankton, representing broadly the taxonomic classes of diatoms + dinoflagellates + chrysophytes (called "Browns"), chlorophytes ("Greens"), cyanobacteria containing phycocyanin ("Cyanos"), and cryptophytes ("Cryptos"). Fluorescence of dissolved organic matter ("yellow substances") was subtracted from original fluorescence measurements by using an ultraviolet-B (UV-B) excitation source, which allows differentiation between algal fluorescence and the fluorescence of "yellow substances" (Beutler et al. 2002). Biomass measured for each phytoplankton group corresponds well with high-performance liquid chromatography (HPLC) analysis (Beutler et al. 2002), with traditional chl $a$ extraction techniques (Gregor and Maršálek 2004), as well as with taxonomic analyses (Gregor et al. 2005). We verified FluoroProbe values with extracted chl $a$ samples taken from the chlorophyll maximum in each basin on each sampling occasion. Water samples were taken with a Van Dorn bottle, $250 \mathrm{~mL}$ of which was filtered onto Whatman GF/F filters, which were subsequently frozen. Chl $a$ was later quantified in the laboratory using ethanol extraction and a spectrophotometer (Wintermans and de Mots 1965; Wetzel and Likens 1991). Regression of fixed chl $a$ with FluoroProbe values was significant $\left(R^{2}=0.75, P<0.0001, n=\right.$ $18)$ with a slope that was not significantly different from 1 $(P=0.15)$, implying that a unit change in FluoroProbe value is equivalent to a unit change in extracted chlorophyll. Pro- 
file data was collected by the FluoroProbe at every few centimetres in the water column. The mean of these measured values were calculated for each metre of depth across the water column, thus generating vertical profiles at the metre scale of the total and spectral phytoplankton groups.

Zooplankton biomass across the entire water column was estimated in $1 \mathrm{~m}$ depth bins using a Laser Optical Plankton Counter (LOPC; ODIM Brooke Ocean Technology, Dartmouth, Nova Scotia, Canada) coupled with a CTD (conductivity, temperature, depth metre; Applied Microsystems Micro CTD, Sidney, British Columbia, Canada) hauled vertically through the lake at the deep point. The LOPC gives total abundance (counts) and because it also measures body size (length and width), can be used to estimate biomass for the entire zooplankton community and for size classes based on equivalent spherical diameter (ESD). ESD is calculated as (length $\times$ width) ${ }^{0.5}$ for each individual zooplankton passing through the LOPC. Biomasses of the entire community were then the summed estimates of biomass (based on biovolume) for each individual $\left(V\right.$ in $\left.\mu \mathrm{m}^{3}\right)$ calculated using the following formula (Finlay et al. 2007):

$$
V=\frac{4}{3} \pi\left(\frac{\mathrm{ESD}}{2}\right)^{3}
$$

$V$ represents the spherical volume, and will thus overestimate the biomass of very ellipsoid-shaped individuals. However, given the fact that we were interested in relative changes in the entire zooplankton community through time, this approximation was adequate for whole community biomass. Furthermore, taxonomic identification of samples by microscopy was carried out to provide more detailed information on community changes. The size classes were chosen to represent different zooplankton groups (Finlay et al. 2007): the small size class (300-500 $\mu \mathrm{m}$ ESD) being composed of rotifers, juvenile copepod stages, and small cladocerans like Bosmina, the medium size class $(500-750 \mu \mathrm{m}$ ESD) representing smaller copepods and Daphnia individuals, while the largest class ( $>750 \mu \mathrm{m}$ ESD) is mainly composed of large Daphnia and copepod species. Vertical profiles were taken on each sampling occasion in 2007 and 2008, but owing to a CTD malfunction, only data from 2008 could be interpreted.

\section{Community composition}

Phytoplankton community composition across the entire water column in each basin was assessed using a tube sampler (with diameter of $1.5 \mathrm{~cm}$ ) that sampled from the surface to a depth of $1 \mathrm{~m}$ above the sediments at the deepest point of each basin. A whole water column sample was taken because of experimentally imposed differences in the relationships between thermal stratification and photic zone depth in each basin. Whole water samples were fixed in acid Lugols solution, and subsamples of phytoplankton from the samples collected in 2007 (days 199 and 213 of year) and from the six sampling dates in 2008 were identified and counted using the Ütermohl method on an inverted microscope. Biovolumes were estimated based on measured cell dimensions and by using geometric formulae for similarly shaped objects (Hillebrand et al. 1999). The goal of this sampling was to ascertain which were the dominant phytoplankton genera responding within each FluoroProbe spectral group, but not to provide a full seasonal assessment of the phytoplankton community responses. For further analyses, we grouped phytoplankton genera into 12 functional/taxonomic groups: all diatoms, cyanobacteria (as either gelatinous colonies or filamentous), all dinoflagellates, all cryptomonads, all euglenoids, chrysophytes (as solitary or colonial), and chlorophytes (as desmids, other nonmotile genera, motile and filamentous).

For zooplankton taxonomic community composition, vertical net hauls from the entire water column were taken using a $54-\mu \mathrm{m}$ mesh net (diameter of $30 \mathrm{~cm}$ and length of $150 \mathrm{~cm}$ ) on each sampling occasion. Zooplankton in the samples were anaesthetized with soda water and preserved in $75 \%$ ethanol. Subsamples $(4 \mathrm{~mL}$ from a $100 \mathrm{~mL}$ dilution of the whole sample taken using a Hensen-Stempel pipettor from a well-mixed sample) were identified by microscopy and enumerated in the laboratory.

\section{Data processing and analyses}

The degree of thermal stratification, the depth of each thermal stratum (epilimnion, metalimnion, and hypolimnion) was calculated in each basin using the YSI temperature profiles. The start of the metalimnion was defined as the shallowest depth at which a $1{ }^{\circ} \mathrm{C}$ temperature decline was observed in the next depth interval and the end of the metalimnion was the last depth at which this differential occurred. Thermocline depth was defined as the midpoint depth of these two extremes of the metalimnion. To characterize the whole water column vertical profiles (1-m resolution) for phytoplankton (FluoroProbe) and zooplankton biomass (LOPC), we calculated the coefficient of variation (CV in water column) of the profiles on each sampling occasion by dividing the standard deviation across all depths by its mean for each spectral/size or total biomass grouping. We also identified the maximum biomass point in each profile (1-m resolution) for each group and recorded both the biomass value of that maximum (Peak biomass) and the depth at which it occurred (Depth of peak) on each date. Also, using these same profiles, we calculated the mean volumetric concentration across the mixed layer (surface of lake to top of the metalimnion) by taking the mean of the mixed layer $1 \mathrm{~m}$ depth-binned interval values, to obtain the Mixed layer mean biomass.

Regression was used to examine the relationships between total phytoplankton and zooplankton biomass and mixed layer depth (irrespective of time) using the $1 \mathrm{~m}$ resolution profile data available for these two groups in 2008. Average volumetric total biomass was calculated (as done for Mixed layer mean biomass) from the lake surface to the top of the metalimnion (to avoid capturing the metalimnion, which is not included in mixed layer model predictions; e.g., Berger et al. 2006). These biomass values were regressed against the average TP value at $2 \mathrm{~m}$ depth on the corresponding sampling date in each basin in 2007 (TP data did not exist for B1 in 2008) to account for the effect nutrients may have on biomass. The residuals of the nutrient regressions were then regressed against the depth of the mixed layer. Linear regressions were initially performed and in the case of phytoplankton a quadratic regression was subsequently used. In the latter case, verification of the presence of a peak in the 
Table 1. Means $( \pm \mathrm{SE})$ of summary statistics of the water column physical and chemical attributes for B3-B1 in each year.

\begin{tabular}{|c|c|c|c|c|}
\hline \multirow[b]{2}{*}{ Physical/abiotic property } & \multicolumn{2}{|c|}{ B3-B1 means (SE) } & \multicolumn{2}{|l|}{$P$ values } \\
\hline & 2007 & 2008 & Lower tail & Upper tail \\
\hline \multicolumn{5}{|l|}{ (a) Temperature $\left({ }^{\circ} \mathbf{C}\right)$} \\
\hline Mean epilimnetic temp. & $-0.54(1.56)$ & $-0.88(0.22)$ & ns & ns \\
\hline Mean metalimnetic temp. & $1.35(1.44)$ & $-0.38(0.56)$ & ns & ns \\
\hline Mean hypolimnetic temp. & $-0.78(0.84)$ & $6.64(0.85)$ & $0.0625^{*}$ & ns \\
\hline \multicolumn{5}{|l|}{ (b) Strata characteristics } \\
\hline Metalimnion starting depth (m) & $-0.67(0.21)$ & $2.83(0.70)$ & ns & 0.0156 \\
\hline Metalimnion end depth (m) & $-0.33(0.21)$ & $2.50(0.34)$ & ns & 0.0156 \\
\hline Thermocline depth (m) & $-0.50(0.18)$ & $2.33(0.40)$ & ns & 0.0156 \\
\hline Epilimnion volume $\left(\mathrm{m}^{3}\right)$ & $-54808(8641)$ & 74605 (18769) & ns & 0.0156 \\
\hline Metalimnion volume $\left(\mathrm{m}^{3}\right)$ & $-21482(7484)$ & $-116524(16267)$ & 0.0156 & ns \\
\hline Hypolimnion volume $\left(\mathrm{m}^{3}\right)$ & $-37399(4247)$ & $-71771(3113)$ & 0.0156 & ns \\
\hline \multicolumn{5}{|l|}{ (c) Dissolved oxygen } \\
\hline$\%$ DO in epilimnion & $17.82(11.65)$ & $-4.65(4.00)$ & $0.0625 *$ & ns \\
\hline$\%$ DO in metalimnion & $-19.23(12.17)$ & $-15.93(5.94)$ & ns & ns \\
\hline \multirow[t]{2}{*}{$\%$ DO in hypolimnion } & $-4.41(3.18)$ & $12.52(13.33)$ & ns & ns \\
\hline & \multicolumn{2}{|c|}{ B3-B2, mean (SE) } & & \\
\hline \multicolumn{5}{|l|}{ (d) Nutrients $\left(\mu \mathrm{g} \cdot \mathrm{L}^{-1}\right)$} \\
\hline $\mathrm{TP}$ at $2 \mathrm{~m}$ depth & $2.46(3.21)$ & $5.37(1.99)$ & ns & ns \\
\hline DIC at $2 \mathrm{~m}$ depth & $-0.32(0.19)$ & $0.12(0.02)$ & ns & 0.0156 \\
\hline DOC at $2 \mathrm{~m}$ depth & $-1.06(0.81)$ & $0.27(0.04)$ & ns & 0.0156 \\
\hline
\end{tabular}

Note: Means in $(a)$ to $(c)$ represent the average across dates of the values in B3 after subtraction of B1 (differences calculated by paired dates). The results for the one-tailed Wilcoxon's $U$ tests are shown wherein the value in the experimental year 2008 was significantly $(P<0.05)$ smaller $(l o w e r$ tail), larger (upper tail), or not significantly different (ns) than in the before-year 2007. An asterisk indicates a marginally $(P<0.1)$ significant difference.

Means in $(d)$ represent the differences between B2 (instead of B1) and B3 paired by date in each year.

relationship within the observed range (as opposed to an asymptotic curve) was done using a Mitchell-Olds and Shaw test (Mitchell-Olds and Shaw 1987).

To assess the effects of thermocline deepening on means of the means of response variables (Tables 1-5), we followed the protocol for BACI experimental designs (StewartOaten et al. 1986). For most response variables (see exceptions below) paired by day of year, the differences in response variable means between the impact and the control basins (i.e., B3-B1) were calculated within each year (2007 or 2008). These differences for the six dates within each year then became the new response variables (unbiased by environmental or seasonal variation affecting the whole lake) that were compared by pairing day of year using a Wilcoxon-Mann-Whitney $U$ test. A nonparametric test, instead of a $t$ test, was used as much of these data were nonnormally distributed, owing to a small number of pairs of observations and because we were unable to normalize them using usual transformations.

There were two exceptions to this analysis procedure because of limited data in 2007, as mentioned above under Schedule. Only data from 2008 were available for the vertical profiles of zooplankton taken with the LOPC. For summary statistics associated with these response variables, we simply compared the mean values in the two basins in 2008 using a $U$ test by matching sampling dates (i.e., not accounting for the before-impact values). The second exception was for the phytoplankton community composition data. In this case, there were only two observations for before-impact 2007. Thus, we modified the procedure as follows: we first subtracted the mean of 2007 values from each day of year observation in 2008 and we then paired these differenced values by day of year in 2008 to compare the responses in the two basins using a $U$ test. All statistical tests were done using JMP 8.0.1 (SAS Institute Inc., Cary, North Carolina).

\section{Results}

\section{Abiotic variables}

In both sampling years (2007 and 2008), the lake stratified in mid-June and fully mixed again in October (Fig. 2). In 2007, the stratification pattern was similar in the three basins, with a mean thermocline depth of $4.5 \mathrm{~m}$. The mean thermocline depth of B1 remained at $4.5 \mathrm{~m}$ in 2008, as in 2007. Experimental mixing in 2008 resulted in a deeper thermocline in the treated B3 (to a mean depth of $7.5 \mathrm{~m}$ ). The mean temperature of each thermal stratum was similar in both years in all basins: the average epilimnetic temperature was $21-24{ }^{\circ} \mathrm{C}$, the metalimnetic temperature ranged from $16{ }^{\circ} \mathrm{C}$ to $18{ }^{\circ} \mathrm{C}$, and the hypolimnetic temperature ranged from $6{ }^{\circ} \mathrm{C}$ to $8{ }^{\circ} \mathrm{C}$. There were no significant differences in the mean temperatures of the upper strata, but our mixing treatment raised the mean temperature of the hypolimnion in the experimental B3 by $6.6{ }^{\circ} \mathrm{C}$ (Table 1a). Furthermore, in B3, the hypolimnion first dropped below $8 \mathrm{~m}$, and then disappeared completely toward the end of the August in 2008 (Fig. 2). Thermocline, epilimnion, and metalimnion depths were significantly deeper by $2-3 \mathrm{~m}$ in the experimental B3, as a result of our mixing treatment (Table 1b). Thus epilimnetic volume was increased while 
Table 2. Means $( \pm \mathrm{SE})$ for summary statistics of the water column distribution of phytoplankton biomass in spectral groups (FluoroProbe data) for B3-B1 in each year.

\begin{tabular}{|c|c|c|c|c|}
\hline \multirow[b]{2}{*}{ FluoroProbe spectral group } & \multicolumn{2}{|c|}{ B3-B1 means (SE) } & \multicolumn{2}{|l|}{$P$ values } \\
\hline & 2007 & 2008 & Lower tail & Upper tail \\
\hline \multicolumn{5}{|c|}{ (a) Mixed layer mean biomass $\left(\mu \mathrm{g}\right.$ chlorophyll $\left.a \cdot \mathbf{L}^{-1}\right)$} \\
\hline Greens & $0.29(0.07)$ & $1.82(0.22)$ & ns & 0.0156 \\
\hline Cyanos & $0.02(0.04)$ & $-0.09(0.03)$ & 0.0469 & ns \\
\hline Browns & $0.24(0.10)$ & $0.92(0.07)$ & ns & 0.0156 \\
\hline Cryptos & $0.003(0.06)$ & $-0.06(0.05)$ & ns & ns \\
\hline Total Chl & $0.55(0.13)$ & $2.60(0.22)$ & ns & 0.0156 \\
\hline \multicolumn{5}{|l|}{ (b) Depth of peak (m) } \\
\hline Greens & $1.00(1.83)$ & $-4.00(0.73)$ & $0.0625^{*}$ & ns \\
\hline Cyanos & $0.83(1.51)$ & $1.33(0.42)$ & ns & ns \\
\hline Browns & $0.00(1.15)$ & $-3.17(0.65)$ & 0.0469 & ns \\
\hline Cryptos & $0.50(0.76)$ & $-0.67(0.76)$ & ns & ns \\
\hline Total Chl & $0.67(0.84)$ & $-3.33(0.80)$ & 0.0156 & ns \\
\hline \multicolumn{5}{|c|}{ (c) Peak biomass ( $\mu$ g chlorophyll $a \cdot \mathbf{L}^{-1}$ ) } \\
\hline Greens & $-0.56(0.99)$ & $1.41(0.26)$ & ns & 0.0156 \\
\hline Cyanos & $1.05(1.33)$ & $-0.12(0.12)$ & ns & ns \\
\hline Browns & $-1.96(0.94)$ & $-0.45(0.71)$ & ns & ns \\
\hline Cryptos & $-0.67(0.39)$ & $-0.10(0.14)$ & ns & ns \\
\hline Total Chl & $-1.22(2.48)$ & $0.36(0.87)$ & ns & ns \\
\hline \multicolumn{5}{|l|}{ (d) $\mathrm{CV}$ in water column } \\
\hline Greens & $-0.80(0.17)$ & $-0.06(0.06)$ & ns & 0.0156 \\
\hline Cyanos & $-0.03(0.13)$ & $0.20(0.14)$ & ns & ns \\
\hline Browns & $-0.20(0.16)$ & $-0.25(0.08)$ & ns & ns \\
\hline Cryptos & $-0.30(0.13)$ & $0.17(0.10)$ & ns & 0.0156 \\
\hline Total Chl & $-0.36(0.10)$ & $-0.16(0.09)$ & ns & ns \\
\hline
\end{tabular}

metalimnetic and hypolimnetic strata volumes decreased relative to the control basin and year.

The dissolved oxygen (DO) profiles of the basins for 2007 and 2008 did not show important differences between basins (Table 1c). Epilimnetic waters ( $<5 \mathrm{~m}$ depth) in all basins contained $>70 \%$ DO in the experimental year and were slightly lower $(P<0.1)$ in B3. In B3 the deep-water anoxic zone persisted for a few weeks less than in B1 in 2008, but DO levels were consistently low in the deepest parts of both basins.

Profile data for nutrients were only available in the experimental year (2008) and only in the intermediate B2 and the experimental B3 (Appendix A, Fig. A1). In both basins, total phosphorus (TP) peaked between 1 and $3 \mathrm{~m}$, although these peaks lasted longer and were larger in B3 $\left(>15 \mathrm{mg} \cdot \mathrm{L}^{-1}\right)$ than in B2 $\left(11-13 \mathrm{mg} \cdot \mathrm{L}^{-1}\right)$. However, mean TP levels in the epilimnion (2 $\mathrm{m}$ depth) did not differ significantly between B2 and B3 (Table $1 d$ ). This lack of difference may be attributable to the fact that B2 also experienced a deeper thermocline and thus the data are of limited interpretation value. Dissolved inorganic carbon (DIC) and dissolved organic carbon (DOC) were both significantly higher in the experimental B3 than in B2 in 2008 however (Table 1d; Appendix A, Fig. A1). Although we do not have estimates of coloured DOC specifically, most DOC in this lake is likely to be coloured as is typical of lakes of this region (Prairie et al. 2002; Longhi and Beisner 2009).

\section{Plankton profiles}

Total chlorophyll biomass was significantly higher in the experimental basin with thermocline deepening as a result of increases in the Greens and Brown spectral groups and despite a small but significant decline in the Cyano group (Table $2 a$ ). The depth of the peak in total chlorophyll biomass was shallower by over $3 \mathrm{~m}$ in experimental B3 with thermocline deepening compared with the control year when the peak had been deeper in B3 (Table $2 b$ ). This effect was a result mainly of shallower peaks in both the Greens (marginally significant) and the Browns (Table $2 b$ ). Furthermore, the size of the peak in Greens was larger by over $2 \mu \mathrm{g} \cdot \mathrm{L}^{-1}$ compared with the control basin in the control year (Table $2 c$ ). The variation in the distribution of phytoplankton was less homogeneous in the experimental basin in 2008 for the Greens and Cryptos spectral groups (Table $2 d$ ). Phytoplankton total biomass peaks were found in the metalimnion of B1, but were more diffusely spread over the first 4-5 $\mathrm{m}$ of epilimnetic waters in B3 (Fig. 3). This change in distribution of total chl $a$ was attributable mostly to changes in the Greens and Browns, whereas the less abundant Cyanos and Cryptos continued to follow thermocline depth even when it was deepened (Appendix B, Fig. B1).

Zooplankton vertical profiles were only available in 2008 (Appendix C, Fig. C1) and are summarized in Table 3. The 
Table 3. Means ( \pm SE) of summary statistics for the water column distribution of zooplankton size classes (LOPC data) by basin.

\begin{tabular}{|c|c|c|c|c|}
\hline \multirow[b]{2}{*}{ Zooplankton size class } & \multicolumn{2}{|c|}{2008 means $(\mathrm{SE})$} & \multicolumn{2}{|l|}{$P$ values } \\
\hline & B1 & B3 & Lower tail & Upper tail \\
\hline \multicolumn{5}{|c|}{ (a) Mixed layer mean biomass $\left(\mu \mathrm{g} \cdot \mathrm{L}^{-1}\right)$} \\
\hline $300-500 \mu \mathrm{m}$ ESD & $2240(196)$ & $2374(153)$ & ns & ns \\
\hline 500-750 $\mu \mathrm{m}$ ESD & $1693(216)$ & $1180(56)$ & 0.0313 & ns \\
\hline$>750 \mu \mathrm{m}$ ESD & $1415(215)$ & $1226(84)$ & ns & ns \\
\hline Total Zooplankton & $6337(570)$ & $5970(210)$ & ns & ns \\
\hline \multicolumn{5}{|l|}{ (b) Depth of peak (m) } \\
\hline $300-500 \mu \mathrm{m}$ ESD & $3.33(0.21)$ & $5.00(0.52)$ & ns & 0.0313 \\
\hline 500-750 $\mu \mathrm{m}$ ESD & $1.83(0.31)$ & $2.17(0.54)$ & ns & ns \\
\hline$>750 \mu \mathrm{m}$ ESD & $2.17(0.31)$ & $4.17(0.95)$ & ns & ns \\
\hline Total zooplankton & $1.83(0.31)$ & $3.33(0.33)$ & ns & 0.0313 \\
\hline \multicolumn{5}{|c|}{ (c) Peak biomass $\left(\mu \mathrm{g} \cdot \mathbf{L}^{-1}\right)$} \\
\hline $300-500 \mu \mathrm{m}$ ESD & $3762(228)$ & $3089(80)$ & $0.0781 *$ & ns \\
\hline 500-750 $\mu \mathrm{m}$ ESD & $3918(417)$ & $1727(129)$ & 0.0156 & ns \\
\hline$>750 \mu \mathrm{m}$ ESD & $3334(245)$ & $2969(431)$ & ns & ns \\
\hline Total zooplankton & $10864(868)$ & $7862(494)$ & 0.0156 & ns \\
\hline \multicolumn{5}{|l|}{ (d) $\mathrm{CV}$ in water column } \\
\hline $300-500 \mu \mathrm{m}$ ESD & $0.43(0.07)$ & $0.23(0.06)$ & 0.0313 & ns \\
\hline 500-750 $\mu \mathrm{m}$ ESD & $0.73(0.10)$ & $0.31(0.06)$ & 0.0156 & ns \\
\hline$>750 \mu \mathrm{m}$ ESD & $0.94(0.13)$ & $0.79(0.08)$ & ns & ns \\
\hline Total zooplankton & $0.45(0.07)$ & $0.18(0.03)$ & 0.0156 & ns \\
\hline
\end{tabular}

distribution of total zooplankton biomass demonstrated a mainly epilimnetic dominance in both basins (Appendix C, Fig. C1), with similar mean biomass in the mixed layer, except for the intermediate size class which was lower in B3 (Table $3 a$ ). Mean depth of the total biomass peak was significantly deeper in B3 and was mainly the result of the 300-500 $\mu \mathrm{m}$ size class (Table $3 b$ ). Peak biomass in this group tracked the thermocline depth in both B1 and B3 (Appendix $\mathrm{C}$, Fig. $\mathrm{C} 1(c-d)$ ). The size of the peak in biomass was lower in B3 than in the control B1 for all except the largest size class (Table $3 c$ ), likely reflecting the more homogeneous distribution of biomass for zooplankton < $750 \mu \mathrm{m}$ in this basin (Table $3 d$ ). The largest zooplankton size class $(>750 \mu \mathrm{m}$ ESD) were the rarest.

Mean volumetric total chl $a$ residuals (after removal of TP effects) showed a unimodal relationship with mixed layer depth (Fig. 4a): phytoplankton biomass increased with mixing depth from 0 to around $4 \mathrm{~m}$ and decreased again for deeper epilimnia. The Mitchell-Olds and Shaw (1987) test confirmed that a significant maximum value occurred within the observed range of mixed layer depths $(P<0.001)$. Zooplankton total volumetric biomass (TP residuals) estimated from the LOPC (Fig. 4b) did not show a significant response to the depth of the mixed layer.

\section{Plankton community composition}

From the microscope counts, both nonmotile and motile chlorophyte groups increased significantly in response to our experiment, with the exception of the filamentous group (Table 4). Chlorophyte genera that increased included the desmids (e.g., Cosmarium, Arthrodesmus), other nonmotile genera (e.g., Gloeocystis, Oocystis), and flagellated cells (Chlamydomonas) (genus-level data not shown). There were no significant changes in the composition or distribution of the cyanobacteria. All groups that made up the Brown spectral group increased with thermocline deepening: dinoflagellates (Gymnodinium and Peridinium), diatoms (Aulacoseira, Cyclotella, Synedra, and Rhizosolenia) and both solitary (e.g., Mallomonas and Ochromonas) and colonial (e.g., Chrysosphaerella, Synura, and Uroglena) chrysophytes (Table 4). Cryptophytes (mainly Cryptomonas sp.) also increased with experimental thermocline deepening.

In our experiment, we observed no significant differences in the abundances of cladoceran zooplankton (identified as Daphnia spp. (D. catawba Coker and D. longiremis Sars), Bosmina longirostris Müller and Holopedium gibberum Zaddach) (Table 5). Cyclopoid copepods (Cyclops scutifer Sars, Mesocyclops leuckarti Claus, and Mesocyclops edax Forbes) increased in abundance over the control basin and year (Table 5). Rotifers also responded positively to thermocline deepening, especially the common genera Keratella and Kellicottia (Table 5).

\section{Discussion}

It has become increasingly recognized that thermocline depth is an important and integrative factor for plankton community structure and function in stratified lakes, especially for the phytoplankton, which have more limited motility than other groups (e.g., Berger et al. 2006; Longhi and 
Table 4. Means $( \pm \mathrm{SE})$ biovolumes in $\mu \mathrm{m}^{3} \cdot \mathrm{L}^{-1}$ of summary statistics for phytoplankton functional-taxonomic groups assessed microscopically for B3 and B1 in 2008 after the removal of the mean value for the control year 2007.

\begin{tabular}{lcclll}
\hline & \multicolumn{2}{l}{$2008-2007$ means $(\mathrm{SE})$} & & $P$ values \\
\cline { 2 - 3 } \cline { 5 - 6 } Phytoplankton group & $\mathrm{B} 1$ & $\mathrm{~B} 3$ & & Lower tail & Upper tail \\
\hline Desmid chlorophytes & $-2.18(1.00)$ & $67.43(14.98)$ & & $\mathrm{ns}$ & 0.0156 \\
Nonmotile chlorophytes & $-19.90(6.00)$ & $20.35(15.22)$ & & $\mathrm{ns}$ & 0.0313 \\
Motile chlorophytes & $-3.88(1.47)$ & $10.18(3.16)$ & & $\mathrm{ns}$ & 0.0156 \\
Filamentous chlorophytes & $350.09(330.33)$ & $1.60(1.60)$ & & $\mathrm{ns}$ & $\mathrm{ns}$ \\
Gelatinous cyanobacteria & $-25.92(13.46)$ & $4.07(10.64)$ & & $\mathrm{ns}$ & $\mathrm{ns}$ \\
Filamentous cyanobacteria & $-5.82(1.93)$ & $0.55(3.20)$ & & $\mathrm{ns}$ & $\mathrm{ns}$ \\
All dinoflagellates & $13.77(8.07)$ & $39.50(4.77)$ & & $\mathrm{ns}$ & 0.0313 \\
All diatoms & $-32.65(16.66)$ & $24.35(16.62)$ & & $\mathrm{ns}$ & $0.0781^{*}$ \\
Solitary chrysophytes & $-33.01(12.30)$ & $120.42(32.13)$ & & $\mathrm{ns}$ & 0.0156 \\
Colonial chrysophytes & $-136.58(61.14)$ & $117.31(29.52)$ & & $\mathrm{ns}$ & 0.0313 \\
All cryptomonads & $5.33(8.04)$ & $57.81(7.90)$ & & $\mathrm{ns}$ & 0.0156 \\
All euglenoids & $5.86(5.86)$ & $2.28(1.46)$ & & $\mathrm{ns}$ & $\mathrm{ns}$
\end{tabular}

Note: The results for the one-tailed Wilcoxon's $U$ tests are shown wherein the value in the treatment basin (B3) was significantly $(P<0.05)$ smaller (lower tail), larger (upper tail) or not significantly different (ns) than in the control basin (B1). An asterisk indicates a marginally $(P<0.1)$ significant difference.

Table 5. Means $\left( \pm\right.$ SE) abundances in individuals $\cdot \mathrm{L}^{-1}$ of crustacean zooplankton and common rotifers for B3-B1 in each year.

\begin{tabular}{lcclll} 
& \multicolumn{2}{l}{ B3-B1 means $(\mathrm{SE})$} & & \multicolumn{2}{l}{$P$ values } \\
\cline { 2 - 3 } \cline { 5 - 6 } Zooplankton group & 2007 & 2008 & & Lower tail & Upper tail \\
\hline Total cladocerans & $-0.50(0.86)$ & $0.06(1.46)$ & & $\mathrm{ns}$ & $\mathrm{ns}$ \\
Daphnia spp. & $-0.66(0.55)$ & $-1.71(0.32)$ & & $\mathrm{ns}$ & $\mathrm{ns}$ \\
Bosmina sp. & $0.03(0.30)$ & $1.34(1.36)$ & & $\mathrm{ns}$ & $\mathrm{ns}$ \\
Holopedium & $0.14(0.28)$ & $0.43(0.37)$ & & $\mathrm{ns}$ & $\mathrm{ns}$ \\
Calanoids & $5.34(3.76)$ & $3.95(3.14)$ & & $\mathrm{ns}$ & $\mathrm{ns}$ \\
Cyclopoids & $-0.42(2.02)$ & $13.79(3.52)$ & & $\mathrm{ns}$ & 0.0156 \\
Total rotifers & $-22.01(3.20)$ & $26.21(23.10)$ & & $\mathrm{ns}$ & 0.0156 \\
Keratella sp. & $-5.68(3.06)$ & $31.19(22.25)$ & & $\mathrm{ns}$ & 0.0156 \\
Kellicottia sp. & $-7.86(1.27)$ & $-2.21(1.22)$ & & $\mathrm{ns}$ & 0.0156 \\
Polyarthra sp. & $-6.11(2.49)$ & $-1.05(1.92)$ & & $\mathrm{ns}$ & $\mathrm{ns}$ \\
\hline
\end{tabular}

Note: Means represent the average across dates of the values in B3 after subtraction of B1 (differences calculated by paired dates). The results for the one-tailed Wilcoxon's $U$ tests are shown wherein the value in the experimental year 2008 was significantly $(P<0.05)$ smaller (lower tail), larger (upper tail) or not significantly different (ns) than in the before year 2007.

Beisner 2009). Through a whole-lake experimental manipulation, our study shows, however, that thermocline deepening had effects on the taxonomic and vertical structure as well as the overall biomass production of the plankton community.

Our experimental manipulation effectively deepened the thermocline in the manipulated basin to a mean of $7.5 \mathrm{~m}$ from its normal position around $4.5 \mathrm{~m}$. The most important measured biogeochemical change observed as a result of our experimental treatment was an increase in both organic and inorganic forms of dissolved carbon (and therefore likely colour), with mixing. However measured biogeochemical changes, including the nonsignificant changes in epilimnetic TP do not provide strong evidence because we were unable to compare with the true control basin, but instead to a basin that also experienced some thermocline deepening. In other studies where deeper waters were recirculated, epilimnetic nutrient increases have been observed, as in the case of sediment resuspension with deep-water mixing in enclosures
(Weithoff et al. 2000) and wind-induced destratification in shallow lakes (Kristensen et al. 1992). On the longer term, it remains possible that resuspension of hypolimnetic water directly to the surface and (or) the exposure of a larger segment of lake-bottom sediments to warmer epilimnetic water with deeper thermoclines could lead to a redistribution of nutrients in our lake. In contrast to mixing experiments in which anoxia in the deepest waters of lakes was eradicated through air bubbling (e.g., Visser et al. 1996; Heo and Kim 2004), the anoxic zone remained present in our lake, albeit slightly reduced in duration in the mixed basin.

\section{Phytoplankton community responses}

As predicted by models (e.g., Klausmeier and Litchman 2001; Diehl 2002; Huisman et al. 2004), total epilimnetic phytoplankton biomass responded unimodally to increasing mixed layer (epilimnion) depth. Total biomass increased with mixed layer depth from 1 to around $4 \mathrm{~m}$, after which it decreased again, likely owing to light limitation (1\% of 
Fig. 2. Thermal profiles of each basin of Lac Croche in 2007 and 2008. The unbroken black lines indicate thermocline depth.

B1
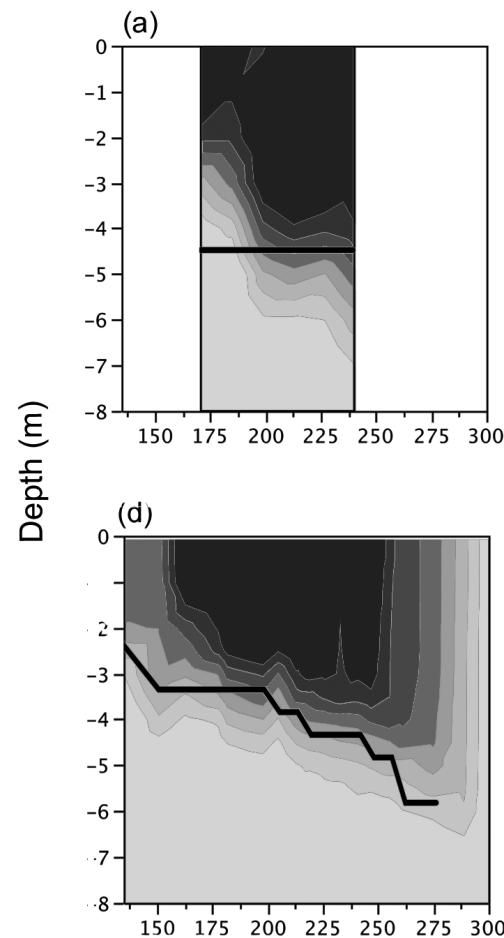

B2

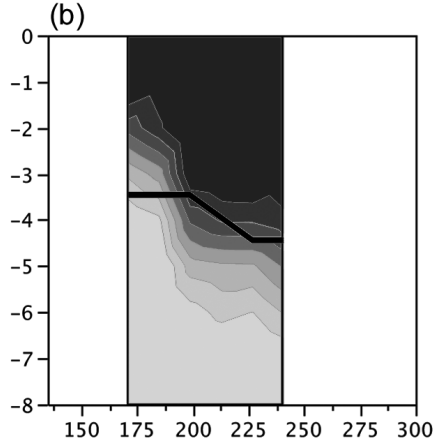

(e)

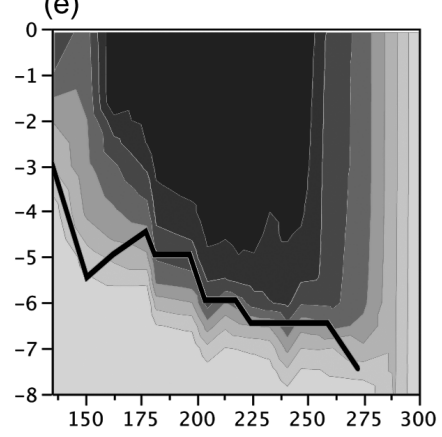

B3
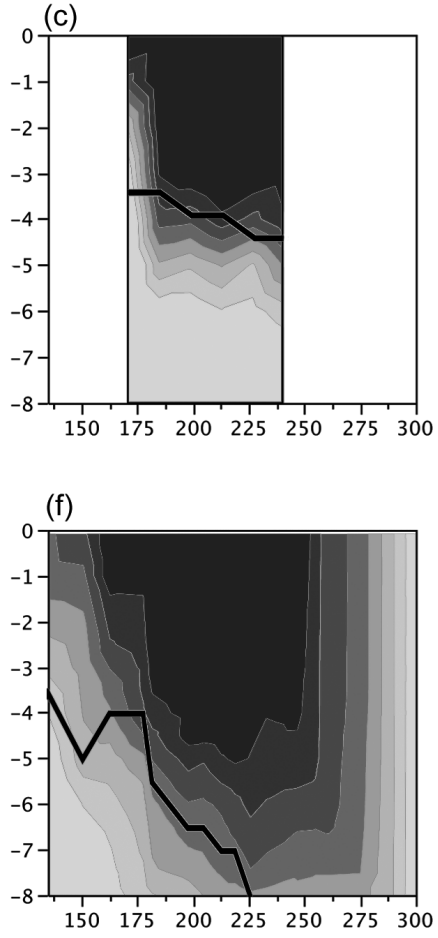

Temperature (degrees Celsius)

$\leq 10.0$

$\leq 11.7$

$\leq 13.3$

$\leq 15.0$

$\leq 16.7$

$\leq 18.3$

$\leq 20.0$

$>20.0$

\section{Day of year}

Fig. 3. Total phytoplankton ( $\mu$ g chlorophyll $a \cdot \mathrm{L}^{-1}$ ) vertical distribution through summers of $2007(a$ and $b)$ and $2008(c$ and $d$ ) for the control (B1) and experimental (B3) basins. The unbroken black lines indicate thermocline depth.

B1

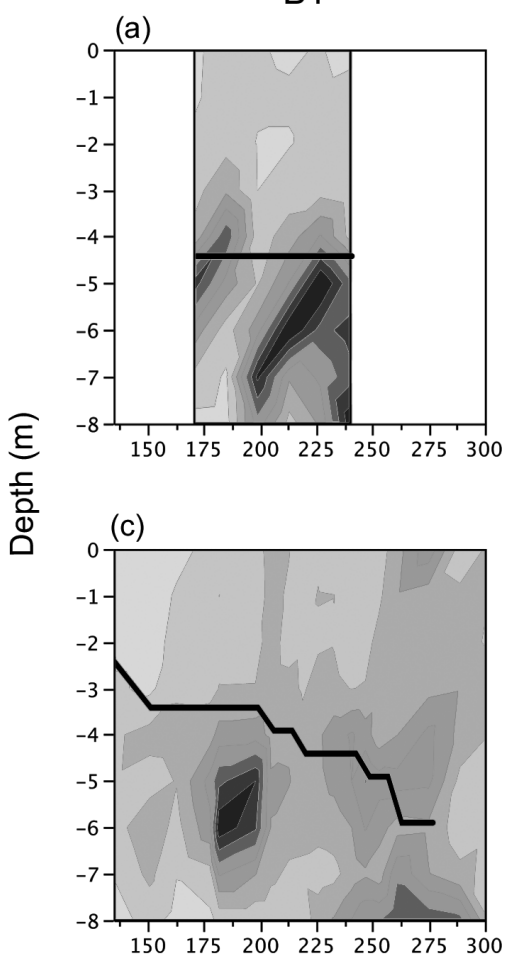

B3
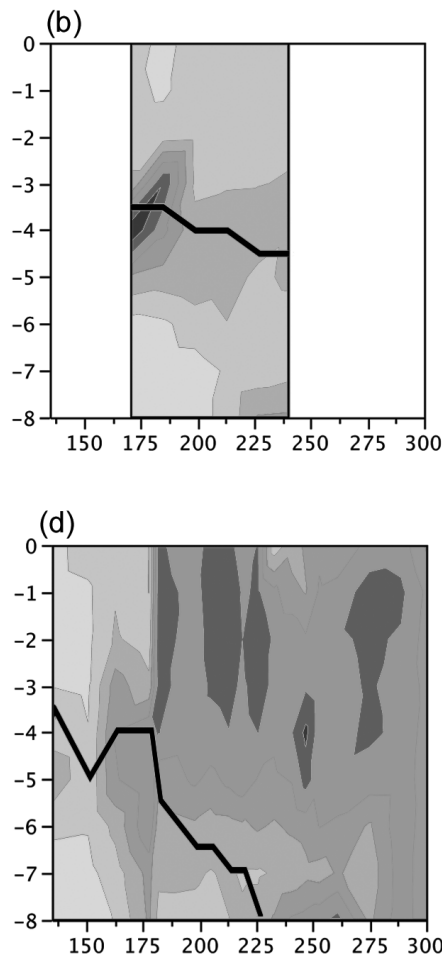

Total chl a

$\left(\mu g \cdot L^{-1}\right)$

$\leq 0.50$

$\leq 1.42$

$\leq 2.33$

$\leq 3.25$

$\leq 4.17$

$\leq 5.08$

$\leq 6.00$

$\longrightarrow 6.00$

Day of year 
Fig. 4. Regressions against the depth of the mixed layer (surface to top of the metalimnion) for each basin in 2008 for the residuals after removal of a TP effect. For $(a)$ total phytoplankton biomass ( $\mu \mathrm{g}$ chlorophyll $\left.a \cdot \mathrm{L}^{-1}\right)$ as estimated by the FluoroProbe, and $(b)$ total zooplankton biomass $\left(\mu \mathrm{g} \cdot \mathrm{L}^{-1}\right)$ as estimated from the LOPC.

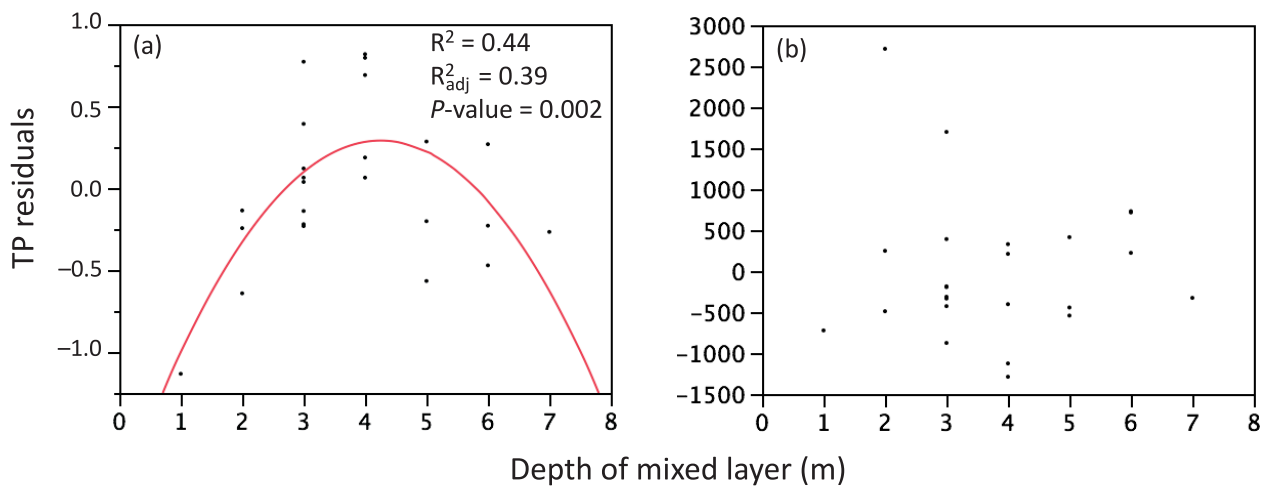

incident light occurs around 6-7 $\mathrm{m}$ depth in this lake) with depth. These results are consistent with other studies of mixing depth effects on phytoplankton, both in models and mesocosm experiments (Diehl 2002; Diehl et al. 2002; Berger et al. 2006), and support the idea that sinking losses dominate at shallow thermocline depths while light limits when thermoclines become too deep.

There have been various theoretical predictions for the differential success of phytoplankton groups to the constraints imposed by thermocline position, based on competitive abilities for light and nutrient acquisition (Huisman and Weissing 1995; Klausmeier and Litchman 2001; Diehl 2002). In our study, only the Greens spectral group increased in peak biomass with increased thermocline depth, but both the dominant biomass groups of Greens and Browns showed significant increases over the entire mixed layer (epilimnion). As a whole, Greens are likely favoured with deeper thermoclines because of the ability of many of their taxa to persist under fluctuating light conditions (Litchman 2000). Additionally, less motile Greens (e.g., desmids) should have been favoured with a deeper thermocline, because of decreased sedimentation losses with greater mixing depth (Reynolds 1984; Diehl et al. 2002; Ptacnik et al. 2003). The desmid Cosmarium depends heavily on turbulence (Reynolds et al. 2002) and it showed the largest response amongst the Greens in our study.

The increases in biomass observed with thermocline deepening in more motile groups like the cryptophytes (including the spectral group response) as well as the dinoflagellates and chrysophytes are likely the result of conditions that enhanced mixotrophy. These latter two groups form the Brown spectral group (along with the diatoms) for which deeper peak biomass positions were also observed. Cryptomonas, the dinoflagellate Gymnodinium sp., and many of the chrysophyte genera that increased with a deeper thermocline are mixotrophs (Sanders and Porter 1988; Olrik 1998). A mixotrophic strategy could have provided these groups with a competitive advantage with deeper thermoclines where nutrient-rich hypolimnetic waters are at a greater distance from the lighted photic region.

Many studies that have involved thermocline deepening have observed decreases in cyanobacteria in relation to mixing depth (Reynolds 1984; Ptacnik et al. 2003; Huisman et al. 2004) and we also observed such an effect for mixed layer biomass. We observed no change at the taxonomic level, nor in other indicators of biomass distribution. Cyanobacteria were only a very minor component of the community in this lake being represented mainly by a gelatinous morphotype (i.e., cells suspended in a gelatinous matrix).

\section{Zooplankton community responses}

Overall, zooplankton biomass was more homogeneously distributed in the deepened thermocline basin (B3) than in the unmanipulated basin (B1). However, this appears to have been the result of differential responses by different size classes of the zooplankton. In the control, zooplankton biomass was greatest around the thermocline because all size classes were aggregated either around the thermocline or in the epilimnion. Under deepened thermocline conditions, the smallest measured size class (300-500 $\mu \mathrm{m}$ ESD) biomass appeared to track the deeper thermocline (although less "accurately" so than in the control basin). Meanwhile the largest zooplankton maintained their position in the epilimnion for the most part. Thackeray et al. (2006) argue that "zooplankton stratification" arises because of plankton aggregation, with greater thermal stratification intensity owing to both passive and active mechanisms. Passive redistribution of zooplankters is caused by the erosion of thermal stratification and should predominantly affect smallerbodied, less mobile individuals. Active movement of individuals toward the most suitable zone of the heterogeneous environment should occur in larger zooplankton. From our study, it appears that the largest zooplankton (e.g., large Daphnia sp. and adult copepods like Mesocyclops sp.) use active movement to maintain their epilimnetic positions where phytoplankton biomass production was high, in spite of changes to the physical structure of the water column. Meanwhile the smallest zooplankton appear to be subject to passive redistribution as predicted (Thackeray et al. 2006), given their continued tracking of the thermocline in our study.

Unlike the response of the primary producers, total volumetric zooplankton biomass across the water column (after accounting for TP differences between basins) did not show a significant relationship with mixed layer depth. These results suggest that top-down effects dominate in the food web of our lake (which is likely given the strong presence of planktivorous fish; J.M. Gunn, unpublished data). Given 
top-down control, thermocline depth and any effect it may have on the phytoplankton resource base should play only a minor role for zooplankton biomass. Such a result is indicative of some of the potential indirect effects one might find in a whole-basin manipulation of thermocline depth, as in our study and warrants a longer term and broader exploration of the food web dynamics with manipulation.

Changes to the zooplankton taxonomic composition reflected the effects one might expect. For example, deeper thermoclines would lead to greater overall turbulence through larger vertical excursions in the mixed layer. Cyclopoid copepods and rotifers (mainly Kellicottia and Keratella) were favoured with thermocline deepening. Such taxa are commonly observed in rivers (Thorp and Mantovani 2005; Sluss et al. 2008), and it has been shown that the turbulence present in rivers induces shifts in communities from Daphnia-dominated to cyclopoid/rotifer-dominated ones (Pace et al. 1992; Basu and Pick 1996). In addition to being more tolerant of turbulent conditions, ambush (raptorial) predators like cyclopoid copepods actually benefit from an enhanced contact rate with prey items at greater turbulence levels (Rothschild and Osborn 1988; Kiørboe and Saiz 1995). Thus, the success of cyclopoid copepods in the experimental basin may have resulted from an enhanced hunting efficiency in waters mixed over a larger vertical expanse. Rotifers, on the other hand, are small individuals with short generation times, allowing them to take advantage of perturbed conditions such as those in our mixed basin. However, because the rotifers that dominated were well protected from invertebrate predation by spines, this suggests that predation pressure on their community was high - further evidence for an increase in encounter rates fuelling the larger population of omnivorous copepods or perhaps other unmeasured invertebrate predators (e.g., Chaoborus sp.). Finally, although we observed a shift to cyclopoids and rotifers, we did not observe strong evidence for a significant decline in Daphnia or cladoceran abundances when controlling for the pre-mix year. These results conform to those of a similar experiment, where no differences in large herbivore density before and after partial experimental destratification were observed (Becker et al. 2006). This lack of response points again to possible top-down control of large herbivores like cladocerans by fish predators.

Overall, experimental thermocline deepening altered the vertical distribution and production of both phytoplankton and zooplankton. Our study represents only one year of experimentation in a single lake. The addition of more experimental years will, without doubt, lead to greater understanding of the responses of the lake ecosystem and its plankton community responses to mixing and thermocline deepening. Nevertheless, it is clear that a modification of mixing regime and thermal stratification can lead to important changes in plankton community structure, and likely to function as well.

\section{Acknowledgments}

Thanks to Sonya Lévesque, Lucja Heintsch, C. Dalmas, Éric Boucher, Tiffany Lachartre, Rich Vogt, Marie-Ève Denis, Maria Maezo, Jason Houle, L. Haslam, D. Dechaine, Marc Amyot, and John Chételat for field and laboratory assistance, and to $\mathrm{H}_{2} \mathrm{O}$ Logics Inc. (SolarBee) and the Station de Biologie des Laurentides for technical and logistical support. We appreciate the comments of Sebastian Diehl and an anonymous reviewer on a previous version of this manuscript. Funding was provided through Natural Sciences and Engineering Research Council of Canada (NSERC) Discovery Grants to B.E.B., J.G., and Y,T,P, as well as through an NSERC Canada Graduate Scholarship to A.C. Assistance from the Canadian Foundation for Innovation (CFI) is also gratefully acknowledged.

\section{References}

Basu, B.K., and Pick, F.R. 1996. Factors regulating phytoplankton and zooplankton biomass in temperate rivers. Limnol. Oceanogr. 41(7): 1572-1577. doi:10.4319/lo.1996.41.7.1572.

Becker, A., Herschel, A., and Wilhelm, C. 2006. Biological effects of incomplete destratification of hypertrophic freshwater reservoir. Hydrobiologia, 559(1): 85-100. doi:10.1007/s10750-0054428-3.

Berger, S.A., Diehl, S., Kunz, T.J., Albrecht, D., Oucible, A.M., and Ritzer, S. 2006. Light supply, plankton biomass, and seston stoichiometry in a gradient of lake mixing depths. Limnol. Oceanogr. 51(4): 1898-1905. doi:10.4319/lo.2006.51.4.1898.

Berger, S.A., Diehl, S., Stibor, H., Trommer, G., Ruhenstroth, M., Wild, A., Weigert, A., Jager, C.G., and Striebel, M. 2007. Water temperature and mixing depth affect timing and magnitude of events during spring succession of the plankton. Oecologia (Berl.), 150(4): 643-654. doi:10.1007/s00442-006-0550-9.

Beutler, M., Wiltshire, K.H., Meyer, B., Moldaenke, C., Lüring, C., Meyerhöfer, M., Hansen, U.P., and Dau, H. 2002. A fluorometric method for the differentiation of algal populations in vivo and in situ. Photosynth. Res. 72(1): 39-53. doi:10.1023/ A:1016026607048. PMID:16228533.

DeStasio, B.T., Jr., Hill, D.K., Kleinhans, J.M., Nibbelink, N.P., and Magnuson, J.J. 1996. Potential effects of global climate change on small north-temperate lakes: Physics, fish, and plankton. Limnol. Oceanogr. 41(5): 1136-1149. doi:10.4319/lo.1996. 41.5.1136.

Diehl, S. 2002. Phytoplankton, light, and nutrients in a gradient of mixing depths: Theory. Ecology, 83(2): 386-398. doi:10.1890/ 0012-9658(2002)083[0386:PLANIA]2.0.CO;2.

Diehl, S., Berger, S., Ptacnik, R., and Wild, A. 2002. Phytoplankton, light, and nutrients in a gradient of mixing depths: field experiments. Ecology, 83(2): 399-411. doi:10.1890/00129658(2002)083[0399:PLANIA]2.0.CO;2.

Fee, E.J., Hecky, R.E., Kasian, S.E.M., and Cruikshank, D.R. 1996. Effects of lake size, water clarity, and climatic variability on mixing depths in Canadian Shield lakes. Limnol. Oceanogr. 41(5): 912-920. doi:10.4319/lo.1996.41.5.0912.

Finlay, K., Beisner, B.E., and Barnett, A.J.D. 2007. The use of the laser optical plankton counter to measure zooplankton size, abundance, and biomass in small freshwater lakes. Limnol. Oceanogr. Methods, 5: 41-49.

France, R. 1997. Land-water linkages: influences of riparian deforestation on lake thermocline depth and possible consequences for cold stenotherms. Can. J. Fish. Aquat. Sci. 54(6): 12991305. doi:10.1139/cjfas-54-6-1299.

George, D.G. 1981. Wind-induced water movements in the South Basin of Windermere. Freshw. Biol. 11(1): 37-60. doi:10.1111/ j.1365-2427.1981.tb01241.x.

Gorham, E., and Boyce, F.M. 1989. Influence of lake surface area and depth upon thermal stratification and the depth of the summer thermocline. J. Great Lakes Res. 15(2): 233-245. doi:10. 1016/S0380-1330(89)71479-9. 
Gregor, J., and Maršálek, B. 2004. Freshwater phytoplankton quantification by chlorophyll a: a comparative study of in vitro, in vivo and in situ methods. Water Res. 38(3): 517-522. doi:10. 1016/j.watres.2003.10.033. PMID:14723919.

Gregor, J., Geris, R., Maršálek, B., Hetesa, J., and Marvan, P. 2005. In situ quantification of phytoplankton in reservoirs using a submersible spectrofluorometer. Hydrobiologia, 548(1): 141151. doi:10.1007/s10750-005-4268-1.

Griesbach, S.J., and Peters, R.H. 1991. The effects of analytical variations on estimates of phosphorus concentration in surface waters. Lake Reservoir Manage. 7(1): 97-106. doi:10.1080/ 07438149109354258.

Harris, G., and Griffiths, F. 1987. On means and variances in aquatic food chains and recruitment to the fisheries. Freshw. Biol. 17(2): 381-386. doi:10.1111/j.1365-2427.1987.tb01058.x.

Heo, W.M., and Kim, B. 2004. The effect of artificial destratification on phytoplankton in a reservoir. Hydrobiologia, 524(1): 229-239. doi:10.1023/B:HYDR.0000036142.74589.a4.

Hillebrand, H., Dürselen, C.-D., Kirschtel, D., Pollingher, U., and Zohary, T. 1999. Biovolume calculation for pelagic and benthic microalgae. J. Phycol. 35(2): 403-424. doi:10.1046/j.1529-8817. 1999.3520403.x.

Huisman, J., and Weissing, F.J. 1995. Competition for nutrients and light in a mixed water column - a theoretical analysis. Am. Nat. 146(4): 536-564 . [E91-E104.] doi:10.1086/285814.

Huisman, J., van Oostveen, P., and Weissing, F.J. 1999. Critical depth and critical turbulence: two different mechanisms for the development of phytoplankton blooms. Limnol. Oceanogr. 44(7): 1781-1787. doi:10.4319/lo.1999.44.7.1781.

Huisman, J., Sharples, J., Stroom, J.M., Visser, P.M., Kardinaal, W.E.A., Verspagen, J.M.H., and Sommeijer, B. 2004. Changes in turbulent mixing shift competition for light between phytoplankton species. Ecology, 85(11): 2960-2970. doi:10.1890/030763.

Jäger, C.G., Diehl, S., and Schmidt, G.M. 2008. Influence of watercolumn depth and mixing on phytoplankton biomass, community composition, and nutrients. Limnol. Oceanogr. 53: 23612373.

Jäger, C.G., Diehl, S., and Emans, M. 2010. Physical determinants of phytoplankton production, algal stoichiometry, and vertical nutrient fluxes. Am. Nat. 175(4): E91-E104. doi:10.1086/ 650728. PMID:20178423.

Kiørboe, T., and Saiz, E. 1995. Planktivorous feeding in calm and turbulent environments, with emphasis on copepods. Mar. Ecol. Prog. Ser. 122: 135-145. doi:10.3354/meps 122135.

Klausmeier, C.A., and Litchman, E. 2001. Algal games: The vertical distribution of phytoplankton in poorly mixed water columns. Limnol. Oceanogr. 46(8): 1998-2007. doi:10.4319/lo. 2001.46.8.1998.

Kristensen, P., Søndergaard, M., and Jeppesen, E. 1992. Resuspension in a shallow eutrophic lake. Hydrobiologia, 228: 101-109. doi:10.1007/BF00006481.

Leibold, M.A. 1990. Resources and predators can affect the vertical distributions of zooplankton. Limnol. Oceanogr. 35(4): 938-944. doi:10.4319/1o.1990.35.4.0938.

Litchman, E. 2000. Growth rates of phytoplankton under fluctuating light. Freshw. Biol. 44(2): 223-235. doi:10.1046/j.13652427.2000.00559.x.

Longhi, M.L., and Beisner, B.E. 2009. Environmental factors controlling the vertical distribution of phytoplankton in lakes. J. Plankton Res. 31(10): 1195-1207. doi:10.1093/plankt/fbp065.

Masson, S., Pinel-Alloul, B., and Dutilleul, P. 2004. Spatial heterogeneity of zooplankton biomass and size structure in southern Quebec lakes: variation among lakes and within lake among epi-, meta- and hypolimnion strata. J. Plankton Res. 26(12): 1441-1458. doi:10.1093/plankt/fbh138.

Mitchell-Olds, T., and Shaw, R. 1987. Regression analysis of natural selection: Statistical inference and biological interpretation. Evolution, 41(6): 1149-1161. doi:10.2307/2409084.

Olrik, K. 1998. Ecology of mixotrophic flagellates with special reference to Chrysophyceae in Danish lakes. Hydrobiologia, 369/ 370: 329-338. doi:10.1023/A:1017045809572.

Pace, M.L., Findlay, S.E.G., and Lints, D. 1992. Zooplankton in advective environments: The Hudson River community and a comparative analysis. Can. J. Fish. Aquat. Sci. 49(5): 10601069. doi:10.1139/f92-117.

Patalas, K. 1984. Mid-summer mixing depths of lakes of different latitudes. Verh. Int. Ver. Theor. Angew. Limnol. 22: 97-102.

Pinel-Alloul, B. 1995. Spatial heterogeneity as a multiscale characteristic of zooplankton community. Hydrobiologia, 300-301(1): 17-42. doi:10.1007/BF00024445.

Prairie, Y.T., Bird, D., and Cole, J.J. 2002. The summer metabolic balance in the epilimnion of southeastern Quebec lakes. Limnol. Oceanogr. 47(1): 316-321. doi:10.4319/lo.2002.47.1.0316.

Ptacnik, R., Diehl, S., and Berger, S. 2003. Performance of sinking and nonsinking phytoplankton taxa in a gradient of mixing depths. Limnol. Oceanogr. 48(5): 1903-1912. doi:10.4319/lo. 2003.48.5.1903.

Reynolds, C.S. 1984. The ecology of freshwater phytoplankton. Cambridge University Press, New York, N.Y.

Reynolds, C.S., Huszar, V., Kruk, C., Naselli-Flores, L., and Melo, S. 2002. Towards a functional classification of the freshwater phytoplankton. J. Plankton Res. 24(5): 417-428. doi:10.1093/ plankt/24.5.417.

Rothschild, B.J., and Osborn, T.R. 1988. Small-scale turbulence and plankton contact rates. J. Plankton Res. 10(3): 465-474. doi:10.1093/plankt/10.3.465.

Sanders, R., and Porter, K. 1988. Phagotropic phytoflagellates. Adv. Microb. Ecol. 10: 167-192.

Schindler, D.W. 1997. Widespread effects of climatic warming on freshwater ecosystems in North America. Hydrol. Process. 11(8): 1043-1067. doi:10.1002/(SICI)1099-1085(19970630) 11:8<1043::AID-HYP517>3.0.CO;2-5.

Schindler, D.W., Beaty, K.G., Fee, E.J., Cruikshank, D.R., Debruyn, E.R., Findlay, D.L., Linsey, G.A., Shearer, J.A., Stainton, M.P., and Turner, M.A. 1990. Effects of climatic warming on lakes of the central boreal forest. Science, 250(4983): 967-970. doi:10.1126/science.250.4983.967. PMID:17746921.

Schindler, D.W., Bayley, S.E., Parker, B.R., Beaty, K.G., Cruikshank, D.R., Fee, E.J., Schindler, E.U., and Stainton, M.P. 1996. The effects of climatic warming on the properties of boreal lakes and streams at the Experimental Lakes Area, northwestern Ontario. Limnol. Oceanogr. 41(5): 1004-1017. doi:10.4319/ 10.1996.41.5.1004.

Scully, N.M., Leavitt, P.R., and Carpenter, S.R. 2000. Century-long effects of forest harvest on the physical structure and autotrophic community of a small temperate lake. Can. J. Fish. Aquat. Sci. 57(S2): 50-59. doi:10.1139/cjfas-57-S2-50.

Sluss, T.D., Cobbs, G.A., and Thorp, J.H. 2008. Impact of turbulence on riverine zooplankton: a mesocosm experiment. Freshw. Biol. 53(10): 1999-2010. doi:10.1111/j.1365-2427.2008.02023.x.

Snucins, E., and Gunn, J. 2000. Interannual variation in the thermal structure of clear and colored lakes. Limnol. Oceanogr. 45(7): 1639-1646. doi:10.4319/lo.2000.45.7.1639.

Stewart-Oaten, A., Murdoch, W.W., and Parker, K.R. 1986. Environmental impact assessment: "Pseudoreplication" in time? Ecology, 67(4): 929-940. doi:10.2307/1939815.

Straile, D., Johnk, K., and Rossknecht, H. 2003. Complex effects of 
winter warming on the physicochemical characteristics of a deep lake. Limnol. Oceanogr. 48(4): 1432-1438. doi:10.4319/lo.2003. 48.4.1432.

Straskraba, M. 1980. Effects of physical variables on production. In The functioning of freshwater ecosystems. Edited by E.D. LeCren and R.H. Lave. International Biological Programme Synthesis Series No. 22, Cambridge University Press, Cambridge, UK. pp. 13-84.

Sverdrup, H.U. 1953. On conditions for the vernal blooming of phytoplankton. ICES J. Mar. Sci. 18(3): 287-295. doi:10.1093/ icesjms/18.3.287.

Thackeray, S.J., George, D.G., Jones, R.I., and Winfield, I.J. 2006. Statistical quantification of the effect of thermal stratification on patterns of dispersion in a freshwater zooplankton community. Aquat. Ecol. 40(1): 23-32. doi:10.1007/s10452-005-9021-3.

Thorp, J.H., and Mantovani, S. 2005. Zooplankton of turbid and hydrologically dynamic prairie rivers. Freshw. Biol. 50(9): 1474-1491. doi:10.1111/j.1365-2427.2005.01422.x.

Visser, P.M., Ibelings, B.W., Van Der Veer, B., Koedood, J., and Mur, L.R. 1996. Artificial mixing prevents nuisance blooms of the cyanobacterium Microcystis in Lake Nieuwe Meer, the Neth- erlands. Freshw. Biol. 36(2): 435-450. doi:10.1046/j.1365-2427. 1996.00093.x.

Visser, A.W., Saito, H., Saiz, E., and Kiørboe, T. 2001. Observations of copepod feeding and vertical distribution under natural turbulent conditions in the North Sea. Mar. Biol. (Berl.), 138: 1011-1019. doi:10.1007/s002270000520.

Weithoff, G., Lorke, A., and Walz, N. 2000. Effects of watercolumn mixing on bacteria, phytoplankton, and rotifers under different levels of herbivory in a shallow eutrophic lake. Oecologia (Berl.), 125(1): 91-100. doi:10.1007/PL00008896.

Wetzel, R.G., and Likens, G. 1991. Limnological analysis. 2nd ed. Springer-Verlag, New York, N.Y.

Winder, M., Reuter, J.E., and Schladow, S.G. 2009. Lake warming favours small-sized planktonic diatom species. Proc. R. Soc. Lond. B Biol. Sci. 276(1656): 427-435. doi:10.1098/rspb.2008. 1200.

Wintermans, J.F., and de Mots, A. 1965. Spectrophotometric characteristics of chlorophylls $a$ and $b$ and their pheophytins in ethanol. Biochim. Biophys. Acta, 109(2): 448-453. doi:10.1016/ 0926-6585(65)90170-6. PMID:5867546.

Appendices A-C appear on the following pages. 


\section{Appendix A}

Fig. A1. Profiles over time for total phosphorus, dissolved inorganic carbon and dissolved organic carbon in 2008. The unbroken black lines indicate thermocline depth.

B2

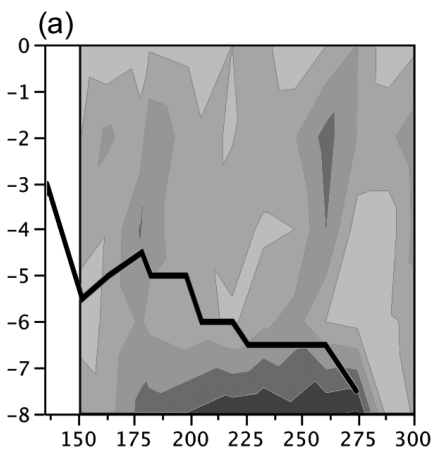

(c)
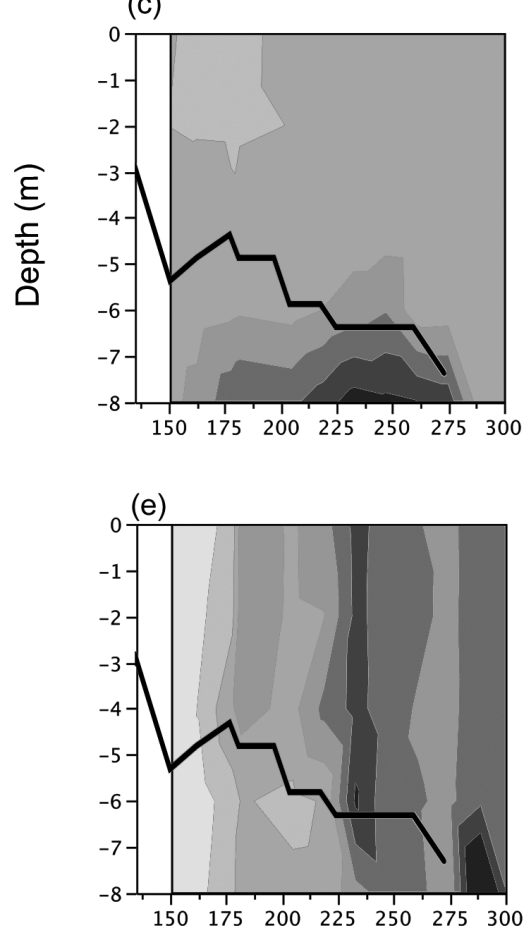

B3

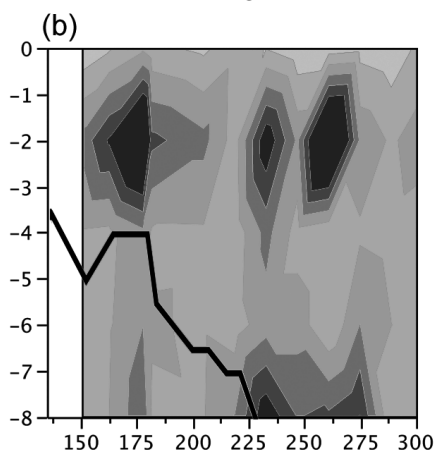

(d)
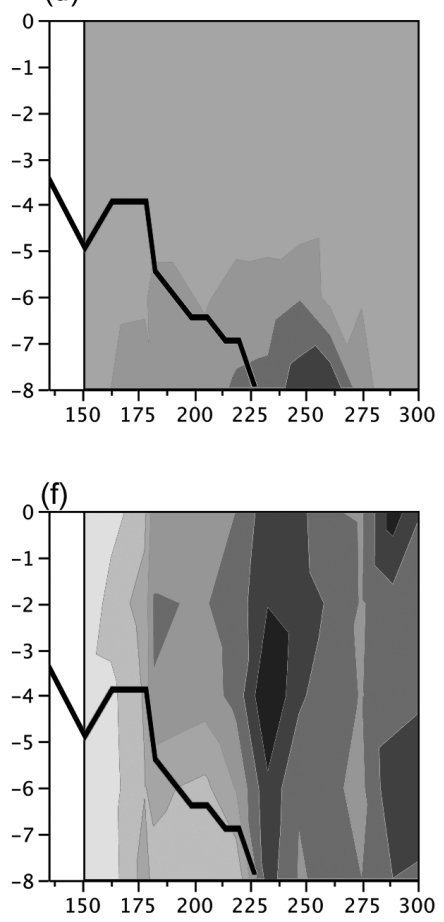

Total phosphorus

$\left(\mu \mathrm{g} \cdot \mathrm{L}^{-1}\right)$

$\leq 5.0$

$\leq 7.0$

$\leq 9.0$

$\leq 11.0$

$\leq 13.0$

$\leq 15.0$

$>15.0$

Day of year 


\section{Appendix B}

Fig. B1. Vertical distribution in 2007 and 2008 for the phytoplankton spectral groups in B1 (first two columns) and B3 (last two columns). Spectral groups are as follows: chlorophytes (Greens) in $(a-d)$, cyanobacteria containing phycocyanin $($ Cyanos) in $(e-h)$, diatoms + dinoflagellates + chrysophytes (Browns) in $(i-l)$, and cryptophytes (Cryptos) in $(m-p)$. The unbroken black lines indicate thermocline depth.

B1

\section{7}

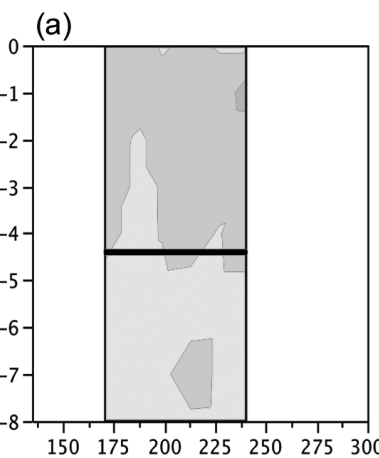

(e)

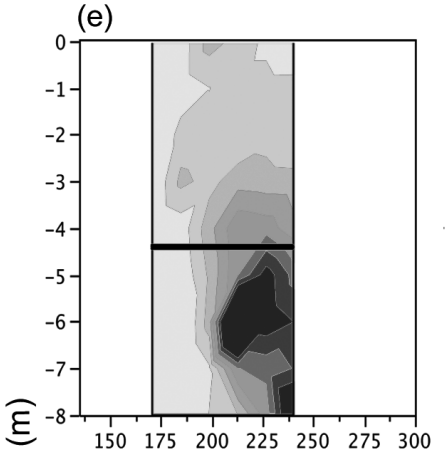

言
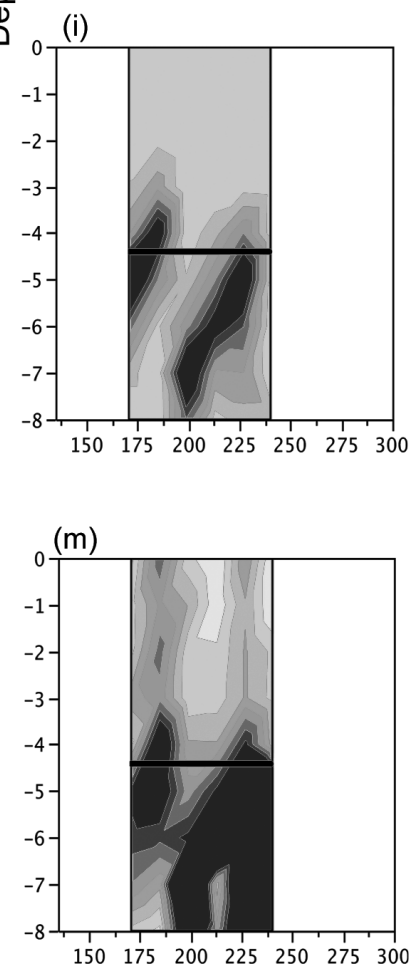

2008
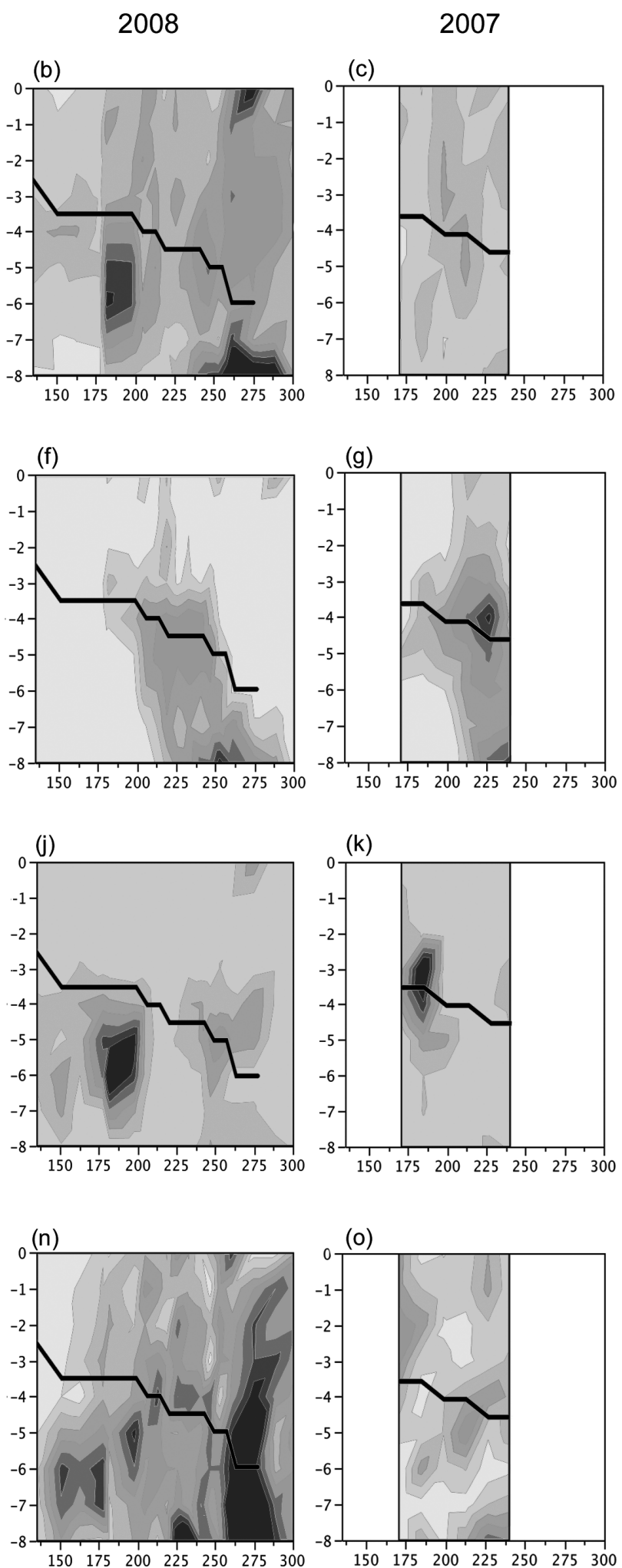

(o)

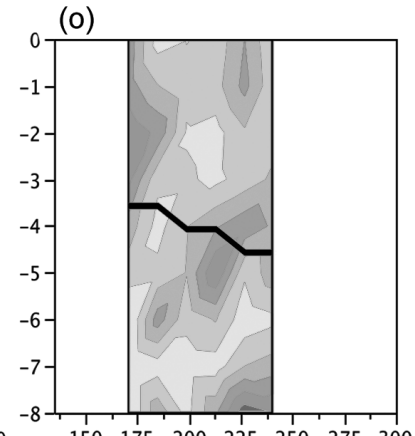

B3

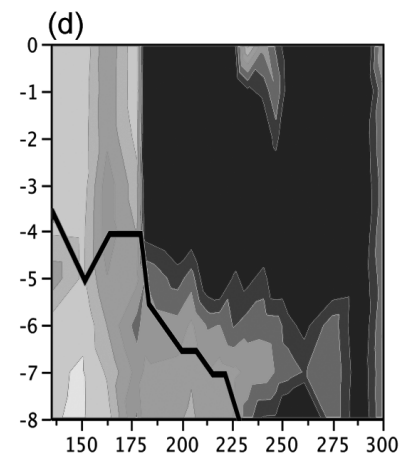

Greens

$\left(\mu \mathrm{g} \cdot \mathrm{L}^{-1}\right)$

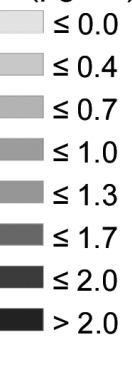

(h)

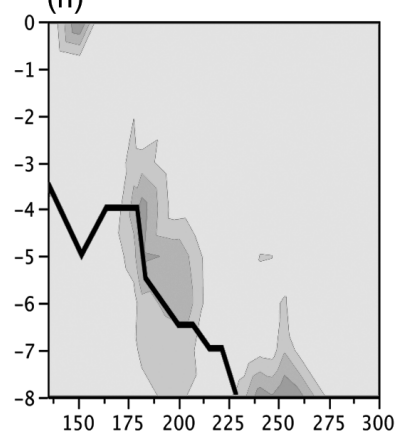

Cyanos

$\left(\mu \mathrm{g} \cdot \mathrm{L}^{-1}\right)$

$\leq 0.3$

$\leq 0.4$

$\leq 0.5$

$\leq 0.6$

$\leq 0.8$

$\leq 0.9$

$\leq 1.0$

$>1.0$

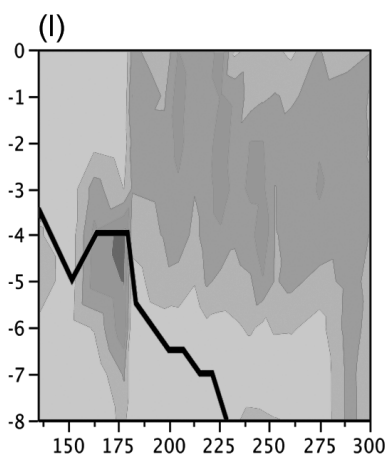

Browns

$\left(\mu \mathrm{g} \cdot \mathrm{L}^{-1}\right)$

$\leq 0.0$

$\leq 0.5$

$\leq 1.0$

$\leq 1.5$

$\leq 2.0$

$\leq 2.5$

$\leq 3.0$

= 3.0

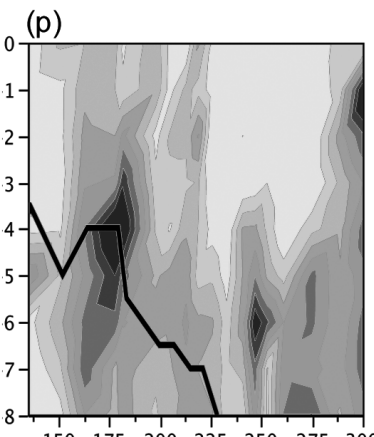

Cryptos

$\left(\mu \mathrm{g} \cdot \mathrm{L}^{-1}\right)$

$\leq 0.10$

$\leq 0.18$

$\leq 0.27$

$\leq 0.35$

$\leq 0.43$

$\leq 0.52$

$\leq 0.60$

> 0.60

Day of year 


\section{Appendix C}

Fig. C1. Zooplankton biomass vertical distribution in 2008 in B1 and B3 for total biomass $(a, b)$, small zooplankton (300-500 $\mu \mathrm{m}$ ESD) $(c$, $d)$, medium zooplankton $(500-750 \mu \mathrm{m}$ ESD) $(e, f)$, and large zooplankton $(>750 \mu \mathrm{m}$ ESD $)(g, h)$. The unbroken black lines indicate thermocline depth.

B1

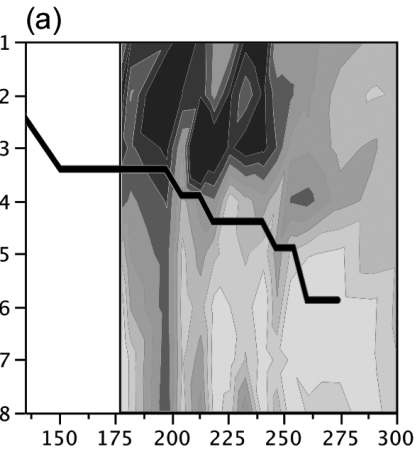

(c)

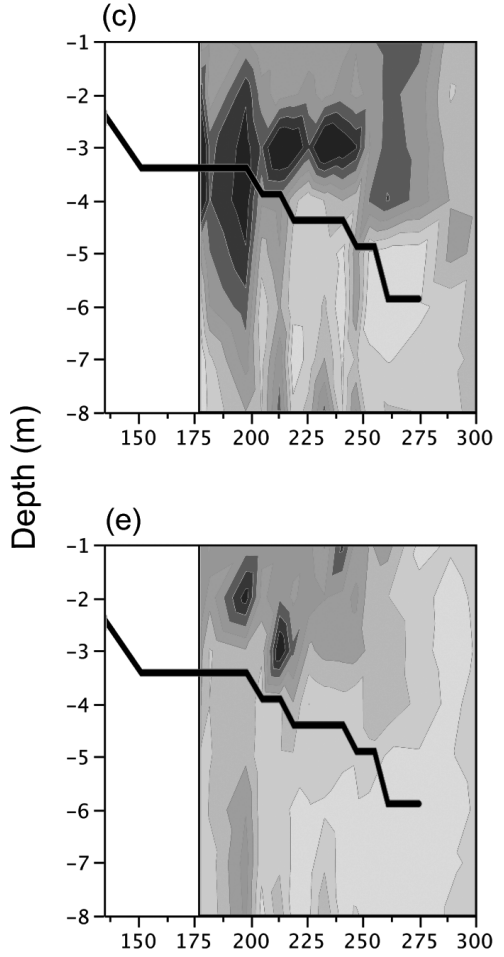

(g)

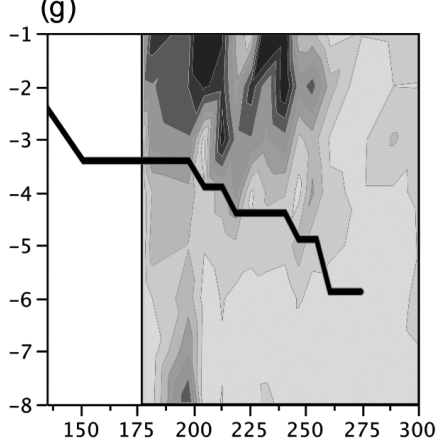

B3

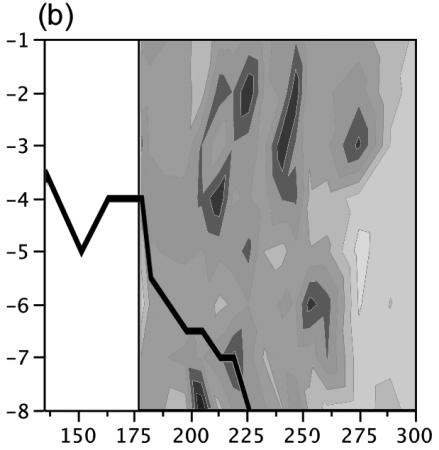

(d)
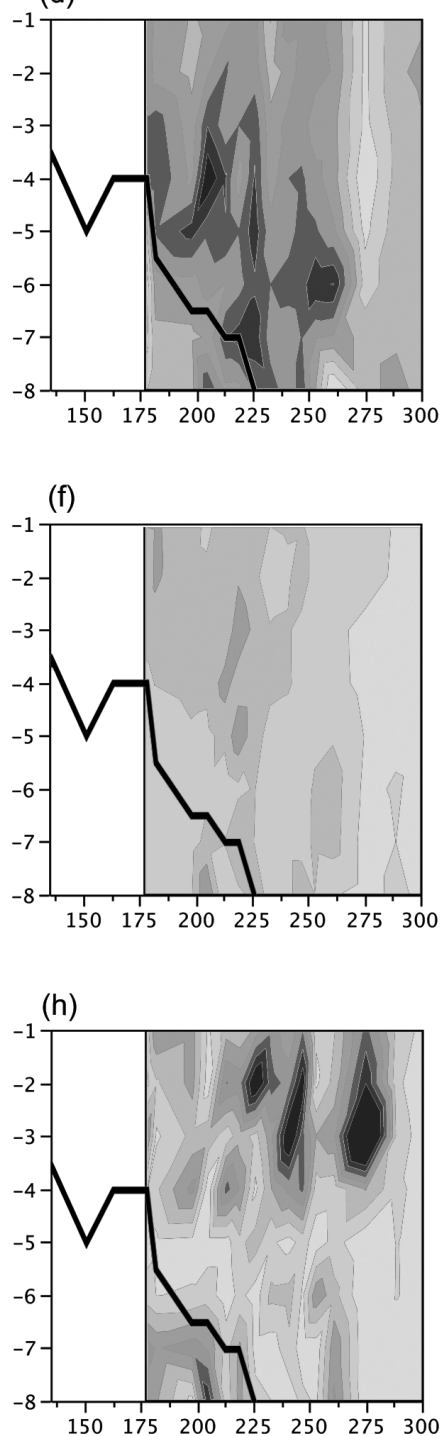

Total zooplankton biomass

$\left(\mu \mathrm{g} \cdot \mathrm{L}^{-1}\right)$

$\leq 3000$

$\leq 4000$

$\leq 5000$

$\leq 6000$

$\leq 7000$

$\square 8000$

$\leq 9000$

$>9000$

300-500 $\mu \mathrm{m}$

$\left(\mu \mathrm{g} \cdot \mathrm{L}^{-1}\right)$

$\leq 1000$

$\square \leq 1417$

$\leq 1833$

$\leq 2250$

$\leq 2667$

$\leq 3083$

$\leq 3500$

c $>3500$

\section{0-750 $\mu \mathrm{m}$}

$\left(\mu \mathrm{g} \cdot \mathrm{L}^{-1}\right)$

$\leq 500$

$\leq 1167$

$\leq 1833$

$\leq 2500$

$\leq 3167$

$\leq 3833$

$\leq 4500$

- $>4500$

$>750 \mu \mathrm{m}$

$\left(\mu \mathrm{g} \cdot \mathrm{L}^{-1}\right)$

$\leq 500$

$\leq 1000$

$\leq 1500$

$\leq 2000$

$\leq 2500$

$\leq 3000$

$\leq 3500$

- 3500

Day of year 